\title{
SYNTHESIS, IN VITRO AND IN VIVO ACTIVITY OF NOVEL 9-DEOXO-9a-AZA-9a-HOMOERYTHROMYCIN A DERIVATIVES; A NEW CLASS OF MACROLIDE ANTIBIOTICS, THE AZALIDES
}

\author{
G. Michael Bright*, Arthur A. Nagel*, Jon Bordner, Kishor A. Desai, \\ Joseph N. Dibrino, Jolanta Nowakowska, Lawrence Vincent, \\ Richard M. Watrous and Frank C. Sciavolino \\ Medicinal Chemistry Department,
}

\author{
Arthur R. English, James A. Retsema*, Margaret R. Anderson, \\ Lori A. Brennan, Roberta J. Borovoy, Caroline R. Cimochowski, \\ James A. Faiella, Arthur E. Girard, Dennis Girard, \\ Carol Herbert, Mary Manousos and Rachel Mason \\ Department of Immunology and Infectious Diseases, \\ Central Research, Pfizer Inc., \\ Groton, CT 06340, U.S.A.
}

(Received for publication February 23, 1988)

\begin{abstract}
A series of erythromycin A-derived semisynthetic antibiotics, featuring incorporation of a basic nitrogen atom into a ring expanded (15-membered) macrocyclic lactone, have been prepared and biologically evaluated. Semisynthetic modifications focused upon (1) varied substitution at the macrocyclic ring nitrogen and (2) epimerization or amine substitution at the C-4" hydroxyl site within the cladinose sugar. In general, the new azalides exhibit improved Gram-negative potency, expanding the spectrum of erythromycin A to fully include Haemophilus influenzae and Neisseria gonorrhoeae. When compared to erythromycin A, the azalides exhibit substantially increased half-life and area-under-the-curve values in all species studied. The overall in vitro/in vivo performance of $N$-methyl, $\mathrm{C}-4$ " epimers $3 a$ and 9; and $\mathrm{C}-4$ " amine 11 identify these compounds as the most interesting erythromycin Asuperior agents. Compound 3a has been advanced to clinical study.
\end{abstract}

Erythromycin $\mathrm{A}$ is a widely used antibiotic in oral outpatient therapy, including pediatrics. It is frequently the agent of choice for treatment of respiratory, cutaneous, Chlamydia, and Campylobacter infections. However, erythromycin $\mathbf{A}$ is not indicated for the treatment of Haemophilus influenzae except with co-administration of sulfonamides. Erythromycin $\mathrm{A}$ is also unstable at gastric $\mathrm{pH}$, and is poorly absorbed with oral dosing.

In our effort to expand the antimicrobial spectrum and to improve upon the pharmacokinetic properties of erythromycin A, the syntheses of erythromycin A-derived 15-membered aza-macrolides depicted in Schemes 1 and 2 were undertaken. Herein are presented the antibacterial profiles of the series, which features varied alkyl substitution at the 9a-aza site within the macrocyclic ring, and modifications at the C-4" site within the cladinose sugar. Additionally, for selected compounds, antiinfective activity against Staphylococcus aureus in mice, and pharmacokinetic profiles in several species are presented. 
Scheme 1.

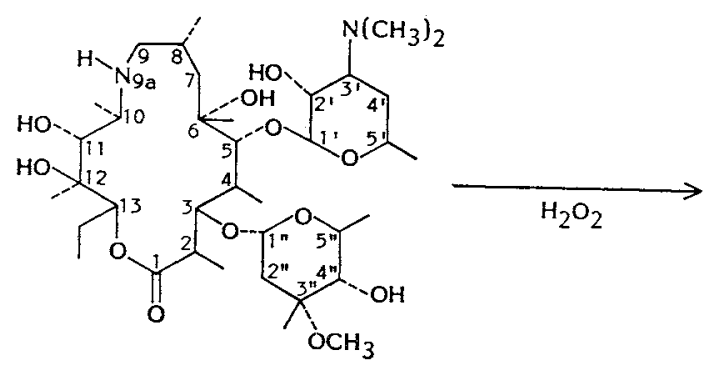

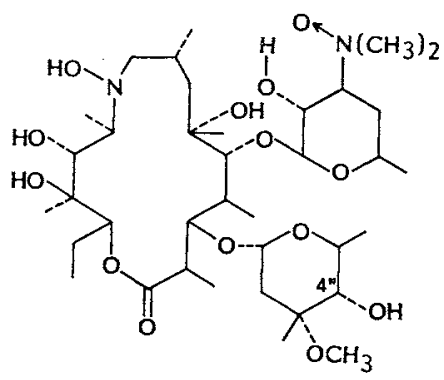

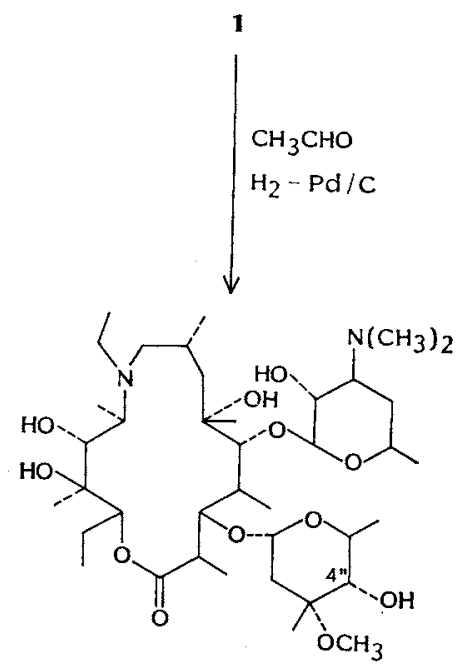

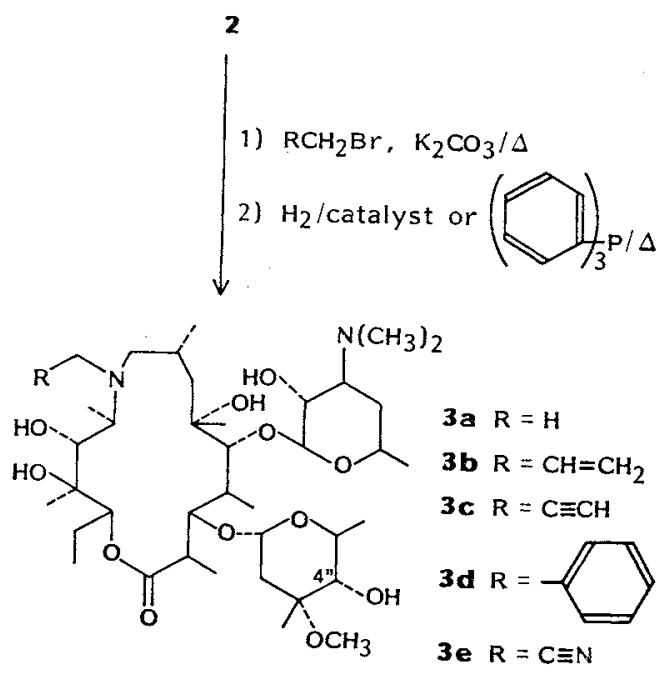

4

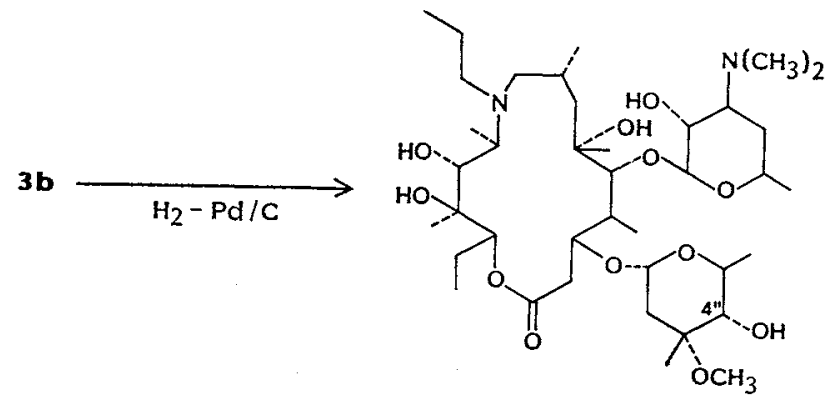

5

\section{Chemistry}

The syntheses of the novel 15 -membered macrolides described in this paper, which are ${ }^{1),+9}$ deoxo-9a-aza-9a-homoerythromycin A derivatives, are depicted in Schemes 1 and 2. We refer to this novel class of 15-membered aza-macrolides as the azalides. In all cases, parent macrolide ${ }^{2}$, 9-deoxo9a-aza-9a-homoerythromycin A (compound 1) and its $\mathbf{C}-4^{\prime \prime}$ epimer $\mathbf{1 2}^{3)}$ served as starting materials. While the simple $N$-ethyl derivative 4 was prepared by a straightforward reductive amination of 1

\footnotetext{
Specifically, this nomenclature follows the instructive examples of p. 501 and p. 506 in ref 1.
} 
Scheme 1. (Continued)

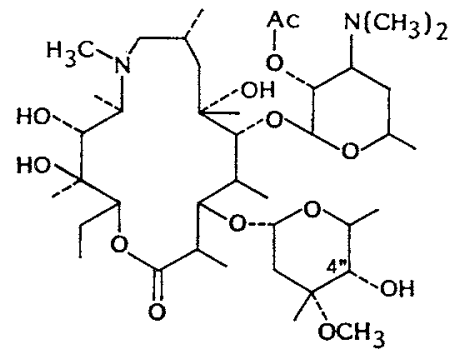

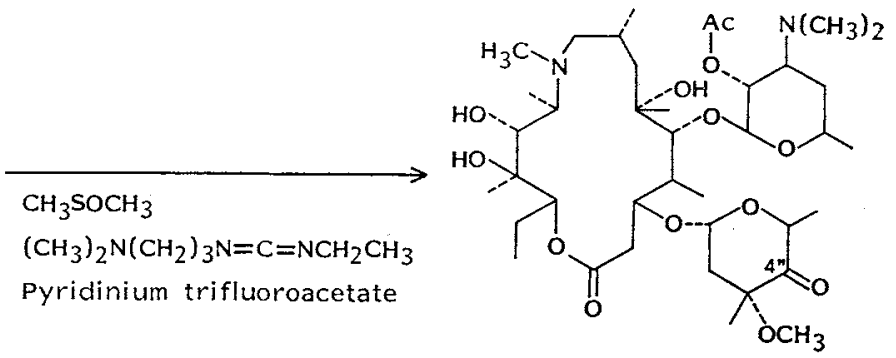

6<smiles>CC(C)OC(C)C</smiles>

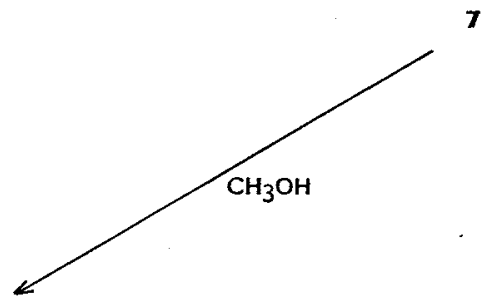

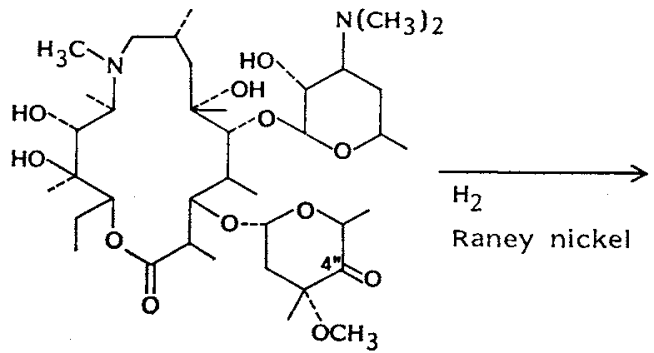

8

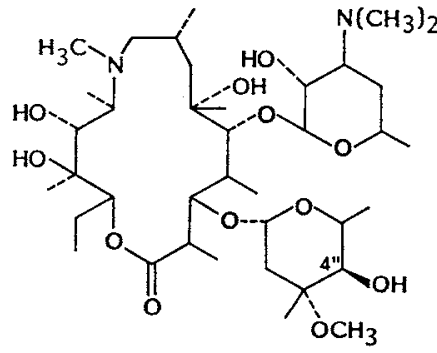
$\mathrm{NH}_{2} \mathrm{OH} \cdot \mathrm{HCl}$

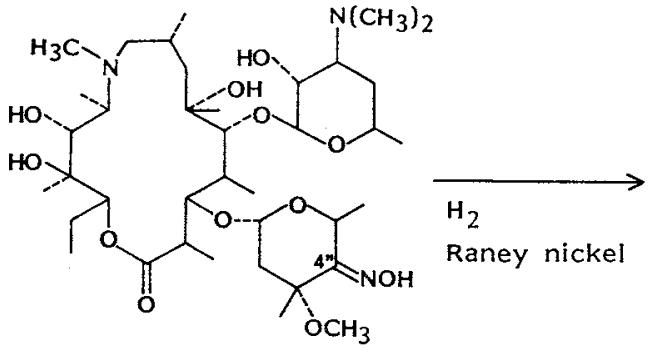

10<smiles>CCC(OC(=O)C(C)C(OC1CC(C)(C)C(N)=C(C)O1)C(C)C(OC1OC(C)CC(N(C)C)C1O)C(O)(CC(C)CN(C)C)C(C)O)C(C)(O)C(C)C</smiles>

11

with acetaldehyde, other $N$-alkyl analogs were prepared by alkyl halide reaction with $N$-oxide $\mathbf{2}$, followed by catalytic hydrogenolysis or triphenylphosphine-induced deoxygenation $(2 \text { to } 3 a \sim 3 e)^{\dagger}$. In the latter approach, oxygen served as a blocking group to prevent quaternization at the $3^{\prime}$-nitrogen

$\dagger$ Unbeknownst to us at the time of our $1 \rightarrow 3 \mathbf{3}$ synthesis, compound $\mathbf{3 a}$ had been synthesized by alternative methods in yet unpublished work: S. DJokIC and G. KorRehel (Pliva Pharmaceuticals, Zagreb, Yugoslavia): Novel derivatives of erythromycin A, procedures for their preparation, and their utilization as antibacterials. Belgium Patent 892,357, July 1, 1982. 
Scheme 2.

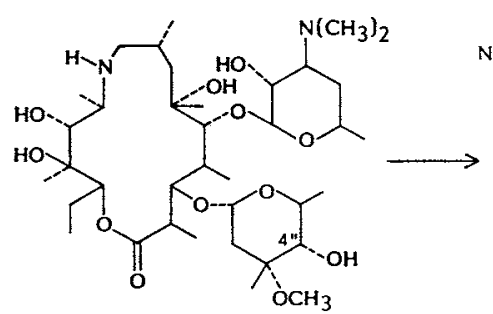

1 (or c-4" epimer 12)

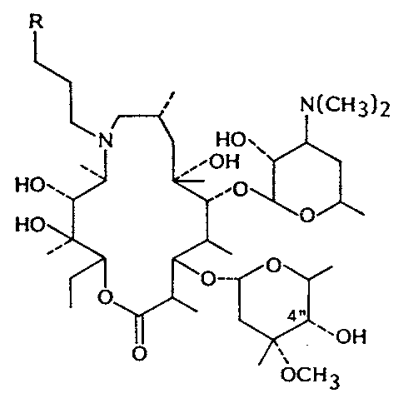

$15 b \mathrm{~b}=\mathrm{NHCHO}$ 15c $\mathrm{R}=\mathrm{N} \equiv \mathrm{C}$.

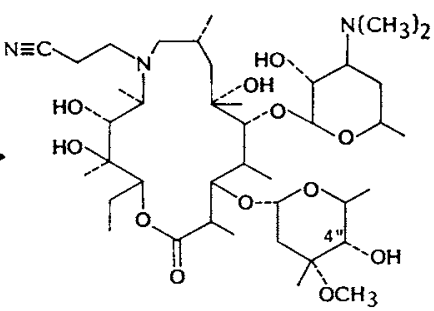

13 (or C-4" epimer 14)

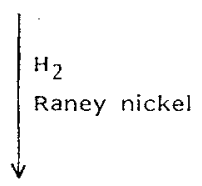

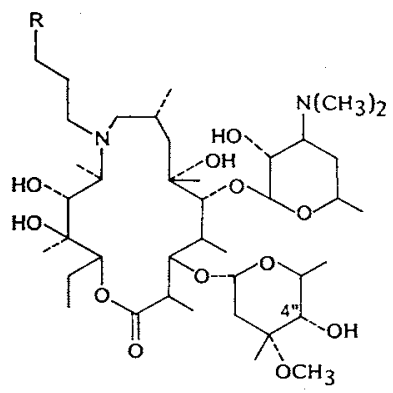

15a (or $\mathrm{C}-4^{11}$ epimer 16) $\mathrm{R}=\mathrm{NH}_{2}$ $\downarrow \begin{aligned} & \text { Isoamyl nitrite } \\ & \text { Acetic acid/s }\end{aligned}$<smiles>CCOC(=O)C(C)C(OC1CC(C)(OC)C(O)C(C)O1)C(C)C(OC1OC(C)CC(N(C)C)C1O)C1(O)CC(C)CN2CCCOC(C(C)(O)CC)C1O2</smiles>

17 (or C-4" epimer 18)

<smiles>CCC(C)(O)C(O)C(C)N(CCN)CC(C)CC(O)(C(C)OC1OC(C)CC(N(C)C)C1O)C(C)C(OC1CC(C)(OC)C(O)=C(C)O1)C(C)C(=O)OC(C)C</smiles>

19

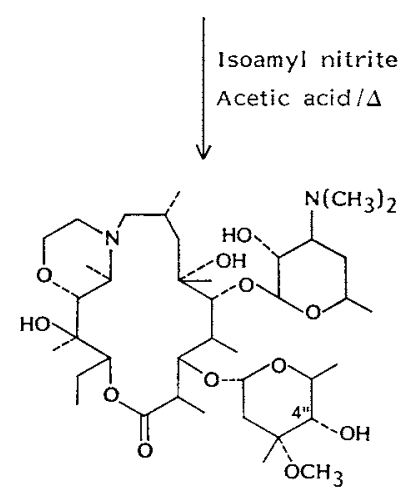

20

of the basic (desosamine) sugar.

Triphenylphosphine was utilized for deoxygenation in the 2 to 3 conversions where the desired products (3b and $3 \mathbf{c}$ ) are vulnerable to over-reduction by catalytic hydrogenation. $N$-Propyl derivative 5 was realized by catalytic reduction of the corresponding $N$-allyl compound $3 \mathbf{b}$; and also by a Barton-type deamination ${ }^{4,5}$ of 15a. In the latter approach to 5 , amine 15a was first $N$-formylated with acetic-formic anhydride ${ }^{e s}$ to afford $\mathbf{1 5 b}$ (Scheme 2). Dehydration of $\mathbf{1 5 b}$ with $p$-toluenesulfonyl chloride in pyridine afforded the corresponding isonitrile 15c, which was then deaminated to 5 by 
Fig. 1. Molecular structure of compound 11.

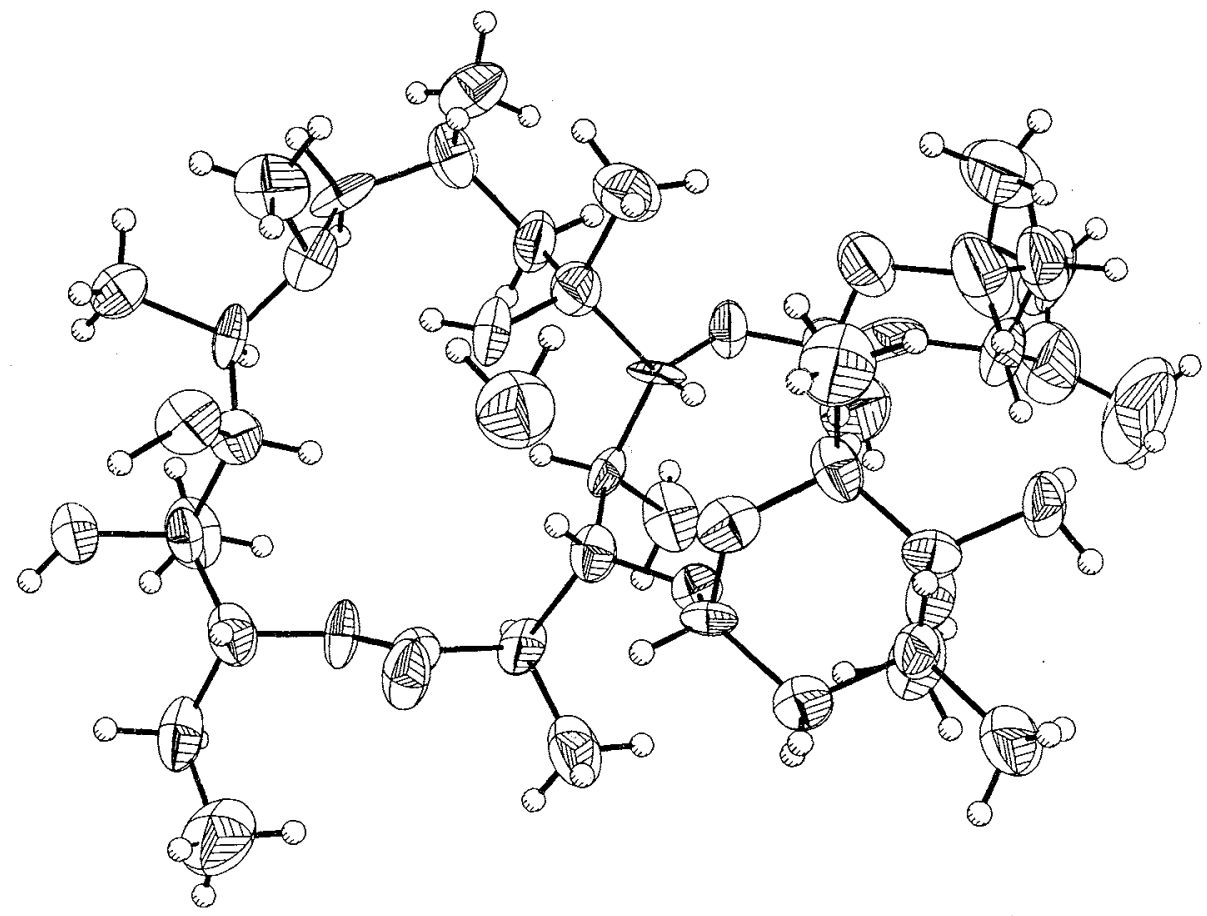

treatment with tri- $n$-butyltin hydride and azobisisobutylnitrile in refluxing xylene.

After protection of the $\mathrm{C}-2^{\prime}$ hydroxyl group by selective acetylation, $N$-methyl analog 3a was efficiently oxidized (modified Moffat-Pfitzner conditions ${ }^{7)}$ ) to the corresponding C-4" ketone 7. Deacetylation of 7 with methanol afforded ketone 8 in high yield; and catalytic hydrogenation of 8 (Raney nickel catalyst) afforded 9, the C-4" epimer of 3a (overall yield from 3a: 39\%).

The stereochemical configuration at $\mathrm{C}-4$ " in compound 9 is evident from NMR comparisons with the erythromycin A-derived epimer 3a. Moreover, compound 9 is obtainable by an alternative synthesis ${ }^{3)}$ utilizing $4^{\prime \prime}$-epi-erythromycin $\mathrm{A}^{8)}$ as its precursor. Acid methanolysis $(\mathrm{HCl}-\mathrm{MeOH})$ of the latter compound, as expected, affords the known ${ }^{9,10\rangle} \mathrm{C}-4^{\prime \prime}$ axial hydroxyl-bearing $\alpha$-methyl arcanoside sugar (F. C. Sciavolino and M. A. Guadliana; privately communicated results, to be published). Treatment of ketone 8 with hydroxylamine afforded the corresponding $\mathrm{C}-4$ " oxime 10, which was converted to $\mathrm{C}-4$ " equatorial amine $\mathbf{1 1}$ by catalytic hydrogenation (Raney nickel catalyst; yield from 3a: $18 \%{ }^{11}$. The relative configuration of the $4^{\prime \prime}$-amine in compound 11 was established via X-ray analysis (Fig. 1).

As shown in Scheme 2, parent compound 1 and its C-4" epimer 12 served as starting materials for the synthesis of bicyclic macrolides 17 and 18 (the C-4" epimer of 17). Thus Michael condensation of 1 and 12 with acrylonitrile and subsequent reduction of the resulting cyanoethyl adducts (13 and 14), afforded the precursors to 17 and 18, amines 15a and 16. Diazotization of $15 a$ or 16 with isoamyl nitrite in glacial acetic acid produced the corresponding 7-membered heterocyclic derivatives $\mathbf{1 7}$ and 18, respectively. Similarly, treatment of amine 19 (prepared by sodium borohydride-cobaltous chloride ${ }^{12)}$ reduction of the $N$-cyanomethyl compound $3 \mathrm{e}^{\dagger}$ with isoamyl nitrite - acetic acid afforded

\footnotetext{
Attempts to reduce 3e by catalytic hydrogenation produced exclusively hydrogenolysis product 1 .
} 
Table $1 .{ }^{13} \mathrm{C}$ Chemical shift assignments of representative azalides ${ }^{\mathrm{a}}$.

\begin{tabular}{|c|c|c|c|c|c|c|}
\hline Carbon $^{b}$ & $3 \mathbf{a}$ & 9 & 11 & $3 c$ & $15 a$ & 18 \\
\hline C-1 & $179.00 \mathrm{~s}$ & $178.81 \mathrm{~s}$ & $178.71 \mathrm{~s}$ & 178.20 & $177.27 \mathrm{~s}$ & $176.61 \mathrm{~s}$ \\
\hline$C-1^{\prime}$ & $102.84 \mathrm{~d}$ & $102.59 \mathrm{~d}$ & $102.96 \mathrm{~d}$ & $102.83 \mathrm{~d}$ & $102.97 \mathrm{~d}$ & $102.62 \mathrm{~d}$ \\
\hline $\mathrm{C}-1^{\prime \prime}$ & $94.41 \mathrm{~d}$ & $95.16 \mathrm{~d}$ & $95.00 \mathrm{~d}$ & $94.77 \mathrm{~d}$ & $95.62 \mathrm{~d}$ & $96.37 \mathrm{~d}$ \\
\hline $\mathrm{C}-5$ & $83.14 \mathrm{~d}$ & $83.14 \mathrm{~d}$ & $83.63 \mathrm{~d}$ & $83.56 \mathrm{~d}$ & $84.13 \mathrm{~d}$ & $83.91 \mathrm{~d}$ \\
\hline $\mathrm{C}-3$ & $78.07 \mathrm{~d}$ & $77.66 \mathrm{~d}$ & $77.85 \mathrm{~d}$ & $77.97 \mathrm{~d}$ & $79.13 \mathrm{~d}$ & $81.03 \mathrm{~d}$ \\
\hline$C-4^{\prime \prime}$ & $77.64 \mathrm{~d}$ & $77.52 \mathrm{~d}$ & $62.44 \mathrm{~d}$ & $77.63 \mathrm{~d}$ & $78.11 \mathrm{~d}$ & $79.60 \mathrm{~d}$ \\
\hline C-13 & $77.44 \mathrm{~d}$ & $74.47 \mathrm{~d}$ & $77.46 \mathrm{~d}$ & $77.52 \mathrm{~d}$ & $77.73 \mathrm{~d}$ & $77.79 \mathrm{~d}$ \\
\hline $\mathrm{C}-12$ & $74.08 \mathrm{~s}$ & $74.32 \mathrm{~s}$ & $72.81 \mathrm{~s}$ & $74.88 \mathrm{~s}$ & $74.75 \mathrm{~s}$ & $74.30 \mathrm{~d}$ \\
\hline$C-6$ & $73.67 \mathrm{~s}$ & $74.16 \mathrm{~s}$ & $73.72 \mathrm{~s}$ & $73.86 \mathrm{~s}$ & $74.54 \mathrm{~s}$ & $74.12 \mathrm{~s}$ \\
\hline C-11 & $73.35 \mathrm{~d}$ & $73.56 \mathrm{~d}$ & $73.99 \mathrm{~d}$ & $74.02 \mathrm{~d}$ & $74.42 \mathrm{~d}$ & $74.25 \mathrm{~d}$ \\
\hline$C-3^{\prime \prime}$ & $72.92 \mathrm{~s}$ & $73.77 \mathrm{~s}$ & $74.39 \mathrm{~s}$ & $72.84 \mathrm{~s}$ & $72.93 \mathrm{~s}$ & $73.62 \mathrm{~s}$ \\
\hline $\mathrm{C}-2^{\prime}$ & $70.80 \mathrm{~d}$ & $71.07 \mathrm{~d}$ & $71.08 \mathrm{~d}$ & $70.77 \mathrm{~d}$ & $71.08 \mathrm{~d}$ & $71.19 \mathrm{~d}$ \\
\hline C-9 & $70.00 \mathfrak{t}$ & $70.20 \mathrm{t}$ & $70.21 \mathrm{t}$ & $63.31 \mathrm{t}$ & $64.56 \mathrm{t}$ & $68.73 \mathrm{t}$ \\
\hline$C-5^{\prime}$ & $68.87 \mathrm{~d}$ & $68.27 \mathrm{~d}$ & $68.52 \mathrm{~d}$ & $68.82 \mathrm{~d}$ & $68.87 \mathrm{~d}$ & $68.31 \mathrm{~d}$ \\
\hline$C-5^{\prime \prime}$ & $65.79 \mathrm{~d}$ & $65.60 \mathrm{~d}$ & $66.63 \mathrm{~d}$ & $65.60 \mathrm{~d}$ & $65.66 \mathrm{~d}$ & $65.46 \mathrm{~d}$ \\
\hline $\mathrm{C}-3^{\prime}$ & $65.59 \mathrm{~d}$ & $63.52 \mathrm{~d}$ & $65.83 \mathrm{~d}$ & $65.52 \mathrm{~d}$ & $65.53 \mathrm{~d}$ & $63.34 \mathrm{~d}$ \\
\hline C- 10 & $62.55 \mathrm{~d}$ & $62.72 \mathrm{~d}$ & $62.19 \mathrm{~d}$ & $61.08 \mathrm{~d}$ & $58.98 \mathrm{~d}$ & $63.08 \mathrm{~d}$ \\
\hline $3^{\prime \prime}-\mathrm{OCH}_{3}$ & $49.44 \mathrm{q}$ & $49.20 \mathrm{q}$ & $49.42 \mathrm{q}$ & $49.36 \mathrm{q}$ & $49.43 q$ & $49.21 \mathrm{q}$ \\
\hline C-2 & $45.43 \mathrm{~d}$ & $45.49 \mathrm{~d}$ & $45.28 \mathrm{~d}$ & $44.75 \mathrm{~d}$ & $45.10 \mathrm{~d}$ & $45.07 \mathrm{~d}$ \\
\hline C-4 & $42.56 \mathrm{~d}$ & $42.76 \mathrm{~d}$ & $42.08 \mathrm{~d}$ & $43.05 \mathrm{~d}$ & $41.08 \mathrm{~d}$ & $39.93 \mathrm{~d}$ \\
\hline C-7 & $42.14 \mathrm{t}$ & $42.25 \mathrm{t}$ & $42.53 \mathrm{t}$ & $42.02 t$ & $40.76 \mathrm{t}$ & $42.34 \mathrm{t}$ \\
\hline $\mathrm{N}\left(\mathrm{CH}_{3}\right)_{2}$ & $40.32(2) \mathrm{q}$ & $40.36(2) q$ & $40.39(2) \mathrm{q}$ & $40.29(2) \mathrm{q}$ & $40.40(2) q$ & $40.35(2) q$ \\
\hline $\mathrm{NCH}_{3}$ & $36.00 \mathrm{q}$ & $36.10 \mathrm{q}$ & $36.35 \mathrm{q}$ & 一 & 一 & 一 \\
\hline $\mathrm{C}-2^{\prime \prime}$ & $34.60 \mathrm{t}$ & $29.10 \mathrm{t}$ & $35.33 \mathrm{t}$ & $34.70 \mathrm{t}$ & $29.26 \mathrm{t}$ & $29.15 \mathrm{t}$ \\
\hline $\mathrm{C}-4^{\prime}$ & $28.79 \mathrm{t}$ & $29.10 \mathrm{t}$ & $29.00 \mathrm{t}$ & $28.65 \mathrm{t}$ & $29.15 \mathrm{t}$ & $29.08 \mathrm{t}$ \\
\hline $6-\mathrm{CH}_{3}$ & $27.57 \mathrm{q}$ & $27.62 \mathrm{q}$ & $27.50 \mathrm{q}$ & $26.70 \mathrm{q}$ & $26.14 \mathrm{q}$ & $26.77 \mathrm{q}$ \\
\hline C-8 & $26.69 \mathrm{~d}$ & $26.81 \mathrm{~d}$ & $26.84 \mathrm{~d}$ & $26.36 \mathrm{~d}$ & $29.15 \mathrm{~d}$ & $26.65 \mathrm{~d}$ \\
\hline $5^{\prime}-\mathrm{CH}_{3}$ & $21.95 \mathrm{q}$ & $22.01 \mathrm{q}$ & $22.31 \mathrm{q}$ & $21.89 \mathrm{q}$ & $23.28 \mathrm{q}$ & $21.92 \mathrm{q}$ \\
\hline $3^{\prime \prime}-\mathrm{CH}_{3}$ & $21.53 \mathrm{q}$ & $21.53 \mathrm{q}$ & $21.98 \mathrm{q}$ & $21.60 \mathrm{q}$ & $21.39 \mathrm{q}$ & $21.51 \mathrm{q}$ \\
\hline $13-\mathrm{CH}_{2}$ & $21.30 \mathrm{t}$ & $21.47 \mathrm{t}$ & $21.35 \mathrm{t}$ & $21.54 \mathrm{t}$ & $21.08 \mathrm{t}$ & $20.96 t$ \\
\hline $2-\mathrm{CH}_{3}$ & $21.34 \mathrm{q}$ & $21.40 \mathrm{q}$ & $21.55 \mathrm{q}$ & $21.27 \mathrm{q}$ & $21.22 q$ & $21.44 \mathrm{q}$ \\
\hline $5^{\prime \prime}-\mathrm{CH}_{3}$ & $18.11 \mathrm{q}$ & $18.28 \mathrm{q}$ & $18.97 \mathrm{q}$ & $18.09 \mathrm{q}$ & $18.32 \mathrm{q}$ & $17.38 \mathrm{q}$ \\
\hline $8-\mathrm{CH}_{3}$ & $16.30 \mathrm{q}$ & $16.40 \mathrm{q}$ & $16.31 \mathrm{q}$ & $16.58 \mathrm{q}$ & $16.56 \mathrm{q}$ & $16.98 \mathrm{q}$ \\
\hline $12-\mathrm{CH}_{3}$ & $14.46 \mathrm{q}$ & $14.41 \mathrm{q}$ & $14.75 \mathrm{q}$ & $14.40 \mathrm{q}$ & $15.30 \mathrm{q}$ & $16.00 \mathrm{q}$ \\
\hline $10-\mathrm{CH}_{3}$ & $11.17 \mathrm{q}$ & $11.27 \mathrm{q}$ & $11.25 \mathrm{q}$ & $11.23 \mathrm{q}$ & $10.99 \mathrm{q}$ & $10.75 \mathrm{q}$ \\
\hline $13-\mathrm{CH}_{3}$ & $8.84 \mathrm{q}$ & $8.95 \mathrm{q}$ & $9.19 \mathrm{q}$ & $10.80 \mathrm{q}$ & $9.64 \mathrm{q}$ & $10.09 q$ \\
\hline $4-\mathrm{CH}_{3}$ & $6.98 \mathrm{q}$ & $7.07 \mathrm{q}$ & $7.43 \mathrm{q}$ & $9.46 \mathrm{q}$ & $7.00 \mathrm{q}$ & $6.75 \mathrm{q}$ \\
\hline $\mathrm{HC} \equiv \mathrm{CCH}_{2}$ & - & - & - & $30.01 \mathrm{~s}$ & 一 & 一 \\
\hline $\mathrm{HC} \equiv \mathrm{CCH}_{2}$ & - & -- & - & $74.03 \mathrm{~d}$ & 一 & - \\
\hline $\mathrm{HC} \equiv \mathrm{CCH}_{2}$ & - & 一 & - & $37.33 \mathrm{t}$ & - & - \\
\hline $\mathrm{NH}_{2} \mathrm{CH}_{2} \mathrm{CH}_{2} \mathrm{CH}_{2}$ & - & 一 & - & - & $48.54 \mathrm{t}$ & - \\
\hline $\mathrm{NH}_{2} \mathrm{CH}_{2} \mathrm{CH}_{2} \mathrm{CH}_{2}$ & - & - & - & $\cdots$ & $39.80 \mathrm{t}$ & - \\
\hline $\mathrm{NH}_{2} \mathrm{CH}_{2} \mathrm{CH}_{2} \mathrm{CH}_{2}$ & - & - & - & - & $35.14 t$ & 一 \\
\hline $\mathrm{OCH}_{2} \mathrm{CH}_{2} \mathrm{CH}_{2} \mathrm{~N}$ & 一 & $一$ & - & 一 & 一 & $67.56 \mathrm{t}$ \\
\hline $\mathrm{OCH}_{2} \mathrm{CH}_{2} \mathrm{CH}_{2} \mathrm{~N}$ & - & - & - & - & - & $47.18 \mathrm{t}$ \\
\hline $\mathrm{OCH}_{2} \mathrm{CH}_{2} \mathrm{CH}_{2} \mathrm{~N}$ & - & - & - & - & 一 & $30.00 t$ \\
\hline
\end{tabular}

a Chemical shifts are in ppm downfield of TMS. ${ }^{13} \mathrm{C}$ NMR spectra were taken in $\mathrm{CDCl}_{3}$ solvent on a Bruker WM250 instrument, with multiplicities determined by distortionless enhancement by polarization transfer.

b For carbon numbering, see compound 1, Scheme 1. 
in analogous fashion, the six-membered heterocycle $20 .{ }^{13} \mathrm{C}$ NMR assignments for six representative azalides are presented in Table 1.

\section{Results and Discussion}

\section{In Vitro Studies}

The azalides all have less potency than erythromycin A vs. Gram-positive isolates (Table 2). They also show cross resistance to erythromycin A-resistant $S$. aureus (Table 2) and Streptococcus pyogenes isolates (MIC $>50 \mu \mathrm{g} / \mathrm{ml}$ for all macrolides). Better Gram-negative activity is observed with all the azalides, except 10, 13, 15a and 16 (Table 2). The degree of Gram-negative activity appears to generally correlate with the increased hydrophilic nature of the compound. Compound 11, the most basic of the experimental macrolides, demonstrates the greatest increase in Gram-negative potency; it is 30 60 times more potent than erythromycin A (Table 2). Comparison of compound 11 with erythromycin A against recent clinical isolates proves it to have broad spectrum activity (Table 3). Its $\mathrm{MIC}_{90}$ vs. Escherichia coli is 0.5 compared with $>64 \mu \mathrm{g} / \mathrm{ml}$ for erythromycin A. It inhibits $90 \%$ of the Enterobacter, Klebsiella and Citrobacter species at $2 \mu \mathrm{g} / \mathrm{ml}$ compared with $>64$ for erythromycin A. It is not active against Proteus species. It is several times more potent than erythromycin A against Neisseria gonorrhoeae and $H$. influenzae (Tables 2 and 3), but four times less potent against Gram-positive clinical isolates (Table 3). A change in the stereochemical configuration of

Table 2. In vitro activity of aza-macrolides.

\begin{tabular}{|c|c|c|c|c|c|c|c|}
\hline \multirow{3}{*}{ Compound } & \multicolumn{6}{|c|}{$\operatorname{MIC}(\mu \mathrm{g} / \mathrm{ml})$} & \multirow{3}{*}{$\begin{array}{l}\text { Haemophilus } \\
\text { influenzae }^{\mathrm{b}}\end{array}$} \\
\hline & \multirow{2}{*}{$\begin{array}{l}\text { Streptococcus } \\
\text { pyogenes }\end{array}$} & \multicolumn{3}{|c|}{ Staphylococcus aureus } & \multicolumn{2}{|c|}{ Escherichia coli } & \\
\hline & & ES & IER & CER & ES & ER & \\
\hline Erythromycin A & $\leq 0.025$ & 0.10 & 6.25 & $>50$ & 1.56 & 100 & 3.12 \\
\hline 1 & $\leq 0.025$ & 0.78 & 50 & $>50$ & 0.78 & 12.5 & $1.56 \sim 0.78$ \\
\hline $3 \AA^{\mathrm{a}}$ & $\leq 0.025$ & 0.39 & 25 & $>50$ & 0.78 & 6.25 & 0.78 \\
\hline $\mathbf{3 b}$ & $\leq 0.025$ & 0.20 & 3.12 & $>50$ & 0.39 & 6.25 & $0.78 \sim 0.39$ \\
\hline $3 \mathbf{c}$ & $\leq 0.025$ & 0.20 & 12.5 & $>50$ & 0.78 & 25 & 1.56 \\
\hline $3 d$ & $\leq 0.025$ & 0.39 & 12.5 & $>50$ & 0.78 & 6.25 & 1.56 \\
\hline $3 \mathbf{e}$ & $\leq 0.025$ & 0.78 & 50 & $>50$ & 0.78 & 25 & 1.56 \\
\hline 4 & $\leq 0.025$ & 0.20 & 6.25 & $>50$ & 0.39 & 6.25 & 0.78 \\
\hline 5 & $\leq 0.025$ & 0.39 & 12.5 & $>50$ & 0.78 & 12.5 & 1.56 \\
\hline 8 & $\leq 0.025$ & 0.39 & 25 & $>50$ & 0.20 & 3.12 & $0.78 \sim 1.56$ \\
\hline $9^{\mathrm{a}}$ & $\leq 0.025$ & 0.39 & 3.12 & $>50$ & 0.78 & 3.12 & 0.39 \\
\hline 10 & 0.10 & 1.56 & $>50$ & $>50$ & 0.39 & 50 & $3.12 \sim 6.25$ \\
\hline 11 & $\leq 0.025$ & 0.78 & 12.5 & $>50$ & 0.05 & 1.56 & 0.20 \\
\hline 12 & $\leq 0.025$ & 0.78 & 25 & $>50$ & 0.78 & 12.5 & 1.56 \\
\hline 13 & 0.05 & 0.39 & 25 & $>50$ & 3.12 & 25 & 3.12 \\
\hline $15 \mathbf{a}$ & 0.78 & 1.56 & $>50$ & $>50$ & 1.56 & 50 & 25 \\
\hline 16 & 0.20 & 3.12 & $>50$ & $>50$ & 3.12 & 50 & 25 \\
\hline 17 & $\leq 0.025$ & 0.20 & 25 & $>50$ & 0.78 & 6.25 & 0.78 \\
\hline 18 & $\leq 0.025$ & 0.39 & 25 & $>50$ & 0.39 & 3.12 & 0.78 \\
\hline 20 & 0.05 & 0.39 & 25 & $>50$ & 1.56 & 25 & 1.56 \\
\hline
\end{tabular}

a $\mathrm{MIC}_{90}$ against Neisseria gonorrhoeae; $0.125 \mu \mathrm{g} / \mathrm{ml}$.

b Average MIC from eight strains.

ES: Erythromycin A-susceptible, ER: erythromycin A-resistant, IER: inducible erythromycin Aresistant, CER : constitutive erythromycin A-resistant. 
Table 3. In vitro potency of $\mathbf{1 1}$ compared to erythromycin A.

\begin{tabular}{|c|c|c|c|}
\hline \multirow{2}{*}{ Organisms (No. of strains) } & \multirow{2}{*}{$\begin{array}{l}\% \text { of strains } \\
\text { inhibited }\end{array}$} & \multicolumn{2}{|c|}{$\mathrm{MIC}(\mu \mathrm{g} / \mathrm{ml})$} \\
\hline & & 11 & Erythromycin A \\
\hline \multirow[t]{2}{*}{ Staphylococcus aureus (10) } & 50 & 1 & 0.25 \\
\hline & 90 & 2 & 0.5 \\
\hline \multirow[t]{2}{*}{ S. epidermidis (14) } & 50 & 0.5 & 0.25 \\
\hline & 90 & 1 & 0.25 \\
\hline $\begin{array}{l}\text { Staphylococcus species } \\
\text { erythromycin-resistant (12) }\end{array}$ & 50 & $>64$ & $>64$ \\
\hline \multirow[t]{2}{*}{ Streptococcus faecalis (15) } & 50 & 4 & 1 \\
\hline & 90 & $>64$ & $>64$ \\
\hline \multirow[t]{2}{*}{ Escherichia coli $(22)$} & 50 & 0.25 & 32 \\
\hline & 90 & 0.5 & $>64$ \\
\hline \multirow[t]{2}{*}{ Enterobacter aerogenes (23) } & 50 & 1 & $>64$ \\
\hline & 90 & 2 & $>64$ \\
\hline \multirow[t]{2}{*}{ E. cloacae (31) } & 50 & 1 & $>64$ \\
\hline & 90 & 2 & $>64$ \\
\hline \multirow[t]{2}{*}{ Klebsiella pneumoniae $(16)$} & 50 & 1 & $>64$ \\
\hline & 90 & 2 & $>64$ \\
\hline \multirow[t]{2}{*}{$K$. oxytoca $(11)$} & 50 & 1 & $>64$ \\
\hline & 90 & 2 & $>64$ \\
\hline \multirow[t]{2}{*}{ Serratia marcescens (18) } & 50 & 8 & $>64$ \\
\hline & 90 & 16 & $>64$ \\
\hline \multirow[t]{2}{*}{ Citrobacter freundii (19) } & 50 & 1 & $>64$ \\
\hline & 90 & 2 & $>64$ \\
\hline \multirow[t]{2}{*}{ Proteus mirabilis (14) } & 50 & $>64$ & $>64$ \\
\hline & 90 & $>64$ & $>64$ \\
\hline \multirow{2}{*}{ P. vulgaris (12) } & 50 & 64 & $>64$ \\
\hline & 90 & $>64$ & $>64$ \\
\hline \multirow[t]{2}{*}{ Neisseria gonorrhoeae PPNG (13) } & 50 & $\leq 0.031$ & 0.125 \\
\hline & 90 & 0.062 & 0.25 \\
\hline \multirow[t]{2}{*}{ Acinetobacter calcoaceticus (13) } & 50 & 0.125 & 2 \\
\hline & 90 & 1 & 8 \\
\hline Pseudomonas aeruginosa (2) & 100 & $>64$ & $>64$ \\
\hline
\end{tabular}

a $\mathrm{MIC}_{50}$ for benzylpenicillin is $>16 \mu \mathrm{g} / \mathrm{ml}$.

the hydroxyl group at C-4" does not lead to significant changes in in vitro activity (epimers $1 \sim 12$, 3a 9, 15a 16, 17 and 18 in Table 2).

\section{Pharmacokinetics}

Key oral pharmacokinetic properties of eight representative azalides compared with erythromycin A are presented in Table 4. Pharmacokinetics were determined in rats, mice, beagles, and monkeys to obtain as broad a profile as possible.

The oral pharmacokinetic properties of each azalide are generally superior to erythromycin $A$ in the animal species studied. Most impressive data were obtained from beagles and rats. Outstanding pharmacokinetic features found in all animals are the long half-life and the large area-under-the-curve. In addition, the $C_{\max }$ values in rat studies with $50 \mathrm{mg} / \mathrm{kg}$ oral administration for all compounds are several-fold higher or equal to the MIC for key organisms ( $S$. aureus, S. pyogenes, H. influenzae) included in the spectrum of an oral community use antibiotic. In contrast to the aza-macrolides, the $\mathbf{C}_{\max }$ of erythromycin $\mathbf{A}$ in the rat $(0.6 \mu \mathrm{g} / \mathrm{ml})$ is considerably less than its average MIC against $H$. 
Table 4. Oral pharmacokinetics of azalides in laboratory animals.

\begin{tabular}{|c|c|c|c|c|c|}
\hline Azalide & Animal & $\begin{array}{l}\text { Oral dose } \\
(\mathrm{mg} / \mathrm{kg})\end{array}$ & $\begin{array}{c}\mathrm{C}_{\max }{ }^{2} \\
(\mu \mathrm{g} / \mathrm{ml})\end{array}$ & $\begin{array}{c}\text { AUC } \\
(\mu \mathrm{g} / \mathrm{ml} \cdot \text { hour })\end{array}$ & $\begin{array}{c}\text { Half-life } \\
\text { (hours) }\end{array}$ \\
\hline \multirow[t]{4}{*}{$3 \mathbf{a}$} & Rat & 50 & 1.3 & 9.5 & 7.7 \\
\hline & Mouse & 50 & 1.6 & 10.0 & 6.4 \\
\hline & Beagle & 10 & 1.4 & 23.4 & 21.0 \\
\hline & Monkey & 10 & 0.43 & 2.9 & 8.7 \\
\hline $3 \mathbf{b}$ & Beagle & 10 & 0.5 & 14.5 & 26.7 \\
\hline 4 & Rat & 50 & 1.9 & 8.7 & 3.1 \\
\hline 5 & Beagle & 10 & 0.9 & 17.9 & 23.3 \\
\hline \multirow[t]{4}{*}{9} & Rat & 50 & 2.6 & 9.2 & 5.6 \\
\hline & Mouse & 50 & 3.1 & 9.0 & 2.0 \\
\hline & Beagle & 10 & 1.5 & 19.0 & 18.9 \\
\hline & Monkey & 10 & 0.5 & 2.2 & 9.5 \\
\hline 11 & Beagle & 10 & 1.8 & 14.6 & 18.0 \\
\hline \multirow[t]{3}{*}{17} & Rat & 50 & 0.7 & 5.5 & 7.2 \\
\hline & Beagle & 10 & 0.9 & 25.5 & 24.3 \\
\hline & Monkey & 10 & 0.3 & 2.4 & 10.9 \\
\hline 18 & Rat & 50 & 0.5 & 5.3 & 13.2 \\
\hline \multirow[t]{4}{*}{ Erythromycin A } & Rat & 50 & 0.6 & 1.54 & 2.1 \\
\hline & Mouse & 50 & 0.9 & 1.5 & 1.2 \\
\hline & Beagle & 10 & 2.5 & 5.2 & 1.5 \\
\hline & Monkey & 10 & 0.2 & 0.2 & 0.6 \\
\hline
\end{tabular}

a $C_{\max }$ : Peak concentration of the antibiotic in serum/plasma.

influenzae $(3.12 \mu \mathrm{g} / \mathrm{ml})$. Extended studies with compound 3a show tissue distributions superior to those of erythromycin $\mathrm{A}^{13)}$. Additionally, in animal model infection studies - e.g., localized thigh infection, anaerobic liver abscesses, etc. - the 9a-methyl derivative $3 a$ consistently and significantly outperforms erythromycin $\mathrm{A}^{13)}$.

In summary, the three best compounds overall are 3a, 9, and 11. They possess an expanded and useful antimicrobial spectrum vs. $H$. influenzae and $N$. gonorrhoeae. Their superior oral in vivo pharmacokinetic profile relative to erythromycin A suggests considerable potential as an improved alternatives to that agent. Compound $3 \mathbf{a}$ has been advanced to clinical study ${ }^{13}{ }^{14}$.

\section{In Vivo Studies}

Representative experimental macrolides having interesting in vitro potency against $S$. aureus ATCC 21351 were advanced to in vivo trial against an acutely-fatal infection produced by that organism in mice. These data, compared with erythromycin $\mathrm{A}$, are presented in Table 5. In vivo activity after oral or parenteral administration was demonstrated with all of the compounds tested. Oral activity matches or exceeds that of erythromycin $A$ in five examples (compounds 3a, 8, 9, 11, and 17).

Only the parenteral activity of compound $\mathbf{1 2}$ exceeds or equals that of erythromycin A. In all cases, parenteral protection is greater than oral protection. Inspection of the Table 5 data clearly indicates that in vitro potency is not a paramount factor in eliciting in vivo potency. Compound $\mathbf{1 5 a}$ has the highest MIC value $(1.56 \mu \mathrm{g} / \mathrm{ml})$, but its subcutaneous $\mathbf{P D}_{50}$ is lower than that of compounds having the lowest MIC value $(0.2 \mu \mathrm{g} / \mathrm{ml}$; compounds 4 and 17).

One of the most striking structure-activity relationships involves comparison of the in vivo profiles of $\mathbf{1}$ and $\mathbf{1 2}$ with their respective $9 \mathrm{a}$-alkylated counterparts $3 \mathbf{a}$ and 9 . While $\mathbf{1}$ and $\mathbf{3 a}$ exhibit equivalent 
Table 5. Activity of azalides against susceptible Staphylococcus aureus ${ }^{\text {a }}$ ATCC 21351 experimental infection in mice.

\begin{tabular}{ccrr}
\hline & \multicolumn{2}{c}{$\mathrm{PD}_{50}(\mathrm{mg} / \mathrm{kg}$ dose $)$} & \multicolumn{1}{c}{ po/sc } \\
\cline { 2 - 3 } $\mathbf{1}$ & \multicolumn{1}{c}{ po } & $\mathrm{sc}$ & $>22$ \\
$\mathbf{3 a}$ & 200 & 9.0 & 8 \\
$\mathbf{4}$ & 71 & 8.5 & $\sim 10$ \\
$\mathbf{8}$ & 149.0 & 15.6 & 2 \\
$\mathbf{9}$ & 100.0 & 43.0 & 3 \\
$\mathbf{1 1}$ & 69 & 22.4 & 8 \\
$\mathbf{1 2}$ & 86.0 & 10.3 & $>83$ \\
$\mathbf{1 3}$ & $>200$ & $\sim 2.4$ & 11 \\
$\mathbf{1 5 a}$ & $>200$ & 18.0 & 20 \\
$\mathbf{1 7}$ & $>200$ & 10 & 3 \\
Erythromycin A control & 100.0 & 30.0 & 32 \\
\hline
\end{tabular}

a. MIC values (erythromycin A-susceptible strain) are presented in Table 1.

parenteral potency, only the 9a-methylated derivative $3 \mathrm{a}$ is orally active ( $\mathrm{PD}_{50}$ 's of $>200 \mathrm{vs} .71 \mathrm{mg} / \mathrm{kg}$, respectively). Similarly, parenterally potent compound $\mathbf{1 2}$ is devoid of oral activity; whereas its parenterally less active 9a-methylated counterpart (9) shows good $\left(\mathrm{PD}_{50} 69 \mathrm{mg} / \mathrm{kg}\right.$ ) oral activity. Also, the 9a-ethyl derivative $\mathbf{4}$ is moderately active orally, in contrast to its parent compound 1. Thus, simple 9a-alkyl substitution appears to be a prerequisite for eliciting oral efficacy.

\section{Experimental}

IR spectra were recorded on a Perkin-Elmer 237B spectrophotometer. ${ }^{1} \mathrm{H}$ NMR spectra were recorded at $60 \mathrm{MHz}$ on a Varian EM360 and at $250 \mathrm{MHz}$ on a Bruker WM250 instrument. ${ }^{13} \mathrm{C} \mathrm{NMR}$ at 100,250 , and $300 \mathrm{MHz}$ were recorded respectively on Varian XL-100, Bruker WM250, and Varian XL-300 spectrometers. Low resolution mass spectra were recorded with a Finnigan $4510 \mathrm{GC}$ instrument, while high resolution mass measurements were obtained with an AEI MS-30 spectrometer. All diffraction data was collected on a Nicolet $\mathrm{R} 3 \mathrm{~m} / \mu$ diffractometer.

TLC measurements utilized Silica gel $60 \mathrm{~F}_{254}(0.25 \mathrm{~mm}$ thickness) plates (E. Merck, Darmstadt) developed with an atomized spray solution of vanillin $(1 \mathrm{~g})$ in $\mathrm{EtOH}-\mathrm{H}_{3} \mathrm{PO}_{4}(100 \mathrm{ml}$ of each), with intense post-spray heating of the plate.

In Vitro Studies, Serum/Plasma Level Determinations, and Acute Systemic Infection Studies

MICs were determined on brain heart infusion agar (Scott Laboratory Inc., Fiskeville, Rhode Island) as the basal medium by the method of ERICSSON and SHERris ${ }^{15)}$ using the multiple inoculator described by STEers et al. ${ }^{162}$. The BHI was enriched and incubation conditions maintained as described previously for the growth of $H$. influenzae and $N$. gonorrhoeae ${ }^{17)}$. For clinical isolates, MIC values were determined by the microtiter broth dilution technique as described previously ${ }^{18)}$.

In the serum/plasma level determinations, antibiotics were administered at either 10 or $50 \mathrm{mg} / \mathrm{kg}$ as an oral gavage in water - carboxymethyl cellulose - Tween 80 . Plasma samples were obtained from the orbital sinus of $\mathrm{CD}$ rats and CD-1 mice using heparinized hematocrit tubes. Blood samples from beagle dogs were obtained from the jugular vein and from the femoral vein of cynomolgus monkeys. Sera were obtained by centrifugation of the samples at refrigerator temperatures. The number of animals used were dogs 10 , rats 20 , mice 20 and monkeys 4 . Plasma/serum samples were then assayed using conventional agar diffusion methods using Micrococcus luteus ATCC 9341 as the bioassay organism.

The acute systemic infections were produced in mice by intraperitoneal inoculation of from one to ten $100 \%$ lethal doses of bacterial cultures suspended in $5 \%$ hog gastric mucin. Mice were treated 
orally or subcutaneously, commencing 0.5 hour after challenge with subsequent treatments at 4 and 24 hours. The dosage range consisted of four different antibiotic concentrations in a 2-fold dilution series administered to 10 mice per dosage level. Percent survival was recorded after a 4-day observation period. After several experiments were completed, survival data were averaged and a $50 \%$ protective dose expressed in $\mathrm{mg} / \mathrm{kg}$ was calculated by the method of BATSON ${ }^{18}$.

9-Deoxo-9a-aza-9a-hydroxy-9a-homoerythromycin A 3'- $N$-Oxide (2)

To a solution of $1(10.0 \mathrm{~g}, 13.6 \mathrm{mmol})$ in $40 \mathrm{ml}$ of $\mathrm{MeOH}$, a total of $50 \mathrm{ml}$ of $30 \%$ aqueous hydrogen peroxide $(0.58 \mathrm{~mol})$ was added dropwise while stirring over a 10 -minute period. After stirring overnight at ambient temperature, the reaction mixture was poured onto a stirred slurry of ice $(200 \mathrm{~g})$, EtOAc $(200 \mathrm{ml})$ and $\mathrm{H}_{2} \mathrm{O}(100 \mathrm{ml})$. Excess hydrogen peroxide was quenched by cautious dropwise addition of saturated aqueous sodium sulfite until a negative starch-iodine test was indicated. The layers were separated, and the aqueous layer was extracted twice with $200 \mathrm{ml}$ portions of EtOAc. The three organic extracts were combined, dried (anhydrous $\mathrm{Na}_{2} \mathrm{SO}_{4}$ ), and concentrated in vacuo to afford 2 as a colorless amorphous solid $(8.6 \mathrm{~g}, 82 \%$ yield).

TLC Rf $0.20\left(\mathrm{CH}_{2} \mathrm{Cl}_{2}-\mathrm{MeOH}-\right.$ conc $\left.\mathrm{NH}_{4} \mathrm{OH}, 6: 1: 0.1\right)$; ${ }^{2} \mathrm{H}$ NMR $\left(60 \mathrm{MHz}, \mathrm{CDCl}_{3}\right) \delta 3.21$ $\left(6 \mathrm{H}, \mathrm{s},\left(\mathrm{CH}_{3}\right)_{2} \mathrm{NO}\right), 3.39\left(3 \mathrm{H}, \mathrm{s}, 3^{\prime \prime}-\mathrm{OCH}_{3}\right) ; \mathrm{MS} m / z 576.3654\left(\mathrm{M}-\mathrm{C}_{8} \mathrm{H}_{18} \mathrm{O}_{4} \mathrm{~N}, \mathrm{C}_{29} \mathrm{H}_{54} \mathrm{O}_{10} \mathrm{~N}\right), 418.2744$ $\left(\mathrm{M}-\mathrm{C}_{16} \mathrm{H}_{30} \mathrm{O}_{7} \mathrm{~N}, \mathrm{C}_{21} \mathrm{H}_{40} \mathrm{O}_{7} \mathrm{~N}\right)$.

\section{9-Deoxo-9a-aza-9a-methyl-9a-homoerythromycin A (3a) (Method A)}

To a well-stirred mixture of $4.83 \mathrm{~g}(6.3 \mathrm{mmol})$ of 2 in $100 \mathrm{ml} \mathrm{of} \mathrm{CH}_{2} \mathrm{Cl}_{2}$ and $69.7 \mathrm{~g}(0.5 \mathrm{~mol})$ of suspended anhydrous $\mathrm{K}_{2} \mathrm{CO}_{3}, 15.7 \mathrm{ml}(35.8 \mathrm{~g}, 0.25 \mathrm{~mol})$ of iodomethane was added dropwise (under nitrogen) over several minutes. The mixture was then stirred under nitrogen at ambient temperature for 3.5 hours. The inorganic solids were removed by filtration. The filter cake was washed with $\mathrm{CH}_{2} \mathrm{Cl}_{2}(250 \mathrm{ml})$. The cake wash solution and filtrate were combined, and then stirred with $\mathrm{H}_{2} \mathrm{O}$ $(300 \mathrm{ml})$ while the $\mathrm{pH}$ was adjusted to $11(6 \mathrm{~N} \mathrm{NaOH})$. The organic phase was separated, washed with an equal volume of $\mathrm{H}_{2} \mathrm{O}$, dried (anhydrous $\mathrm{Na}_{2} \mathrm{SO}_{4}$ ), and concentrated in vacuo to afford a colorless foam $(4.36 \mathrm{~g})$. The entire sample in absolute EtOH $(150 \mathrm{ml})$ was hydrogenated $\left(3.5 \mathrm{~kg} / \mathrm{cm}^{2}\right.$ pressure, $8.0 \mathrm{~g}$ of $10 \%$ palladium-on-carbon catalyst; ambient temperature) for 1.25 hours. The catalyst was filtered, and the solvent was removed in vacuo, affording a colorless foam ( $4.3 \mathrm{~g})$. The crude product was dissolved in $\mathrm{CH}_{2} \mathrm{Cl}_{2}(100 \mathrm{ml})$, and then stirred with $\mathrm{H}_{2} \mathrm{O}(100 \mathrm{ml})$ while the $\mathrm{pH}$ was adjusted to $8.8(6 \mathrm{~N} \mathrm{NaOH})$. The organic and aqueous layers were separated, and the aqueous layer was then extracted twice with $50 \mathrm{ml}$ portions of $\mathrm{CH}_{2} \mathrm{Cl}_{2}$. The three organic extracts were combined, dried (anhydrous $\left.\mathrm{Na}_{2} \mathrm{SO}_{4}\right)$, and concentrated in vacuo to a colorless foam $(3.0 \mathrm{~g})$. The entire sample was taken up in EtOH, and $\mathrm{H}_{2} \mathrm{O}$ was added until the solution became slightly turbid. Upon standing overnight, $1.6 \mathrm{~g}$ ( $34 \%$ yield) of $3 \mathrm{a}$ crystallized from solution.

MP $136^{\circ} \mathrm{C} ;{ }^{1} \mathrm{H}$ NMR $\left(250 \mathrm{MHz}, \mathrm{CDCl}_{3}\right) \delta 3.29\left(3 \mathrm{H}, \mathrm{s}, 3^{\prime \prime}-\mathrm{OCH}_{3}\right), 2.25\left(3 \mathrm{H}, \mathrm{s}, 9 \mathrm{a}-\mathrm{CH}_{3}\right), 2.23$ $\left(6 \mathrm{H}, \mathrm{s}, 3^{\prime}-\mathrm{N}\left(\mathrm{CH}_{3}\right)_{2}\right) ;{ }^{13} \mathrm{C}$ NMR Table 1; MS m/z $749.4\left(\mathrm{M}, \mathrm{C}_{38} \mathrm{H}_{72} \mathrm{O}_{12} \mathrm{~N}_{2}\right), 590.4\left(\mathrm{M}-\mathrm{C}_{8} \mathrm{H}_{18} \mathrm{O}_{2} \mathrm{~N}\right)$, $573.4\left(\mathrm{M}-\mathrm{C}_{8} \mathrm{H}_{17} \mathrm{O}_{3} \mathrm{~N}\right), 432.3\left(\mathrm{M}-\mathrm{C}_{18} \mathrm{H}_{30} \mathrm{O}_{5} \mathrm{~N}\right), 416.3\left(\mathrm{M}-\mathrm{C}_{18} \mathrm{H}_{30} \mathrm{O}_{6} \mathrm{~N}\right), 158.0\left(\mathrm{M}-\mathrm{C}_{50} \mathrm{H}_{58} \mathrm{O}_{10} \mathrm{~N}\right)$.

9-Deoxo-9a-aza-9a-methyl-9a-homoerythromycin A (3a) (Method B)

A mixture of $200 \mathrm{mg}(0.27 \mathrm{mmol})$ of ketone 8 and $76 \mathrm{mg}(0.30 \mathrm{~mol})$ of lithium tri-tert-butoxyaluminum hydride in $30 \mathrm{ml}$ of anhydrous THF was stirred at ambient temperature for 50 minutes. The reaction was diluted with $30 \mathrm{ml}$ of EtOAc $-\mathrm{H}_{2} \mathrm{O}(1: 1)$, and then concentrated in vacuo to a volume of $5 \mathrm{ml}$. After the addition of $30 \mathrm{ml}$ of $\mathrm{H}_{2} \mathrm{O}$, the $\mathrm{pH}$ was adjusted to $6.0(1 \mathrm{~N} \mathrm{HCl})$. The aqueous layer was separated, and the $\mathrm{pH}$ was adjusted to $9.5(1 \mathrm{~N} \mathrm{NaOH})$. The basic solution was twice extracted with $30 \mathrm{ml}$ portions of EtOAc. The combined organic extracts were dried $\left(\mathrm{Na}_{2} \mathrm{SO}_{4}\right)$, and concentrated in vacuo to afford $120 \mathrm{mg}(59 \%$ yield) of $3 \mathrm{a}$ as a colorless foam, identical in all respects to the 3a sample prepared by Method $A$.

\section{9-Deoxo-9a-aza-9a-allyl-9a-homoerythromycin A (3b)}

To a well-stirred mixture of $4.0 \mathrm{~g}(5.2 \mathrm{mmol})$ of 2 in $50 \mathrm{ml}$ of $\mathrm{CHCl}_{3}$ and $28 \mathrm{~g}(0.20 \mathrm{~mol})$ of suspended anhydrous $\mathrm{K}_{2} \mathrm{CO}_{3}, 25 \mathrm{~g}(17.9 \mathrm{ml}, 0.21 \mathrm{~mol})$ of allyl bromide in $10 \mathrm{ml}$ of $\mathrm{CHCl}_{3}$ was added dropwise over 5 minutes. Ambient temperature stirring was continued for 18 hours. Chromato- 
graphy (200 g silica gel, $230 \sim 400$ mesh, elution with $\mathrm{CHCl}_{3}$ - 2-propanol - conc $\mathrm{NH}_{4} \mathrm{OH}(8: 2: 0.1)$ afforded $0.72 \mathrm{~g}$ (colorless foam) of alkylated substrate, sufficiently pure for the next (deoxygenation) step. The entire sample was combined with $0.93 \mathrm{~g}(2.6 \mathrm{mmol})$ of triphenylphosphine in $21 \mathrm{ml}$ of THF, and the resulting mixture was refluxed for 4 hours. Solvent removal in vacuo afforded an oily residue which was dissolved in $150 \mathrm{ml}$ of EtOAc. An equal volume of $\mathrm{H}_{2} \mathrm{O}$ was added and the pH was adjusted to $4.5(6 \mathrm{~N} \mathrm{HCl})$. The separated aqueous phase was extracted with several $150 \mathrm{ml}$ portions of EtOAc. Finally, the aqueous phase was combined with an equal volume of EtOAc, and the $\mathrm{pH}$ was elevated to $10.0\left(10 \% \mathrm{~K}_{2} \mathrm{CO}_{3}\right)$. The phases were separated, and the aqueous was extracted twice with $100 \mathrm{ml}$ of EtOAc. The combined final (3) EtOAc extracts were dried $\left(\mathrm{Na}_{2} \mathrm{SO}_{4}\right)$, and concentrated in vacuo to an amber foam $(0.55 \mathrm{~g})$. Flash chromatography $(50 \mathrm{~g}$ silica gel, $230 \sim 400 \mathrm{mesh}$, elution with $\mathrm{CHCl}_{3}$-2-propanol - conc $\left.\mathrm{NH}_{4} \mathrm{OH}, 15: 1: 0.1\right)$ afforded $408 \mathrm{mg}$ (10\% yield) of $3 \mathrm{~b}$ as a colorless amorphous solid.

TLC Rf $0.36\left(\mathrm{CH}_{2} \mathrm{Cl}_{2}-\mathrm{MeOH}-\right.$ conc $\left.\mathrm{NH}_{4} \mathrm{OH}, 9: 1: 0.1\right) ;{ }^{13} \mathrm{C}$ NMR $\left(100 \mathrm{MHz}, \mathrm{CDCl}_{3}\right) \delta 177.8$, 136.3 and 117.1 (olefinic carbons), 103.0, 95.2, 83.9, 78.5, 78.0, 77.9, 77.7, 74.8, 74.2, 72.8, 70.9, 68.8, $65.6,64.3,64.2,61.2,53.6,49.4,45.0,41.9,41.2,40.3(2), 35.0,29.0,27.8,26.8,22.0,21.6,21.5,21.3$, $18.3,16.5,15.0,11.3,9.7,9.6$; MS $m / z 774.9\left(\mathrm{M}, \mathrm{C}_{40} \mathrm{H}_{74} \mathrm{O}_{12} \mathrm{~N}_{2}\right), 616.4\left(\mathrm{M}-\mathrm{C}_{8} \mathrm{H}_{18} \mathrm{O}_{2} \mathrm{~N}\right), 599.4(\mathrm{M}-$ $\left.\mathrm{C}_{8} \mathrm{H}_{17} \mathrm{O}_{3} \mathrm{~N}\right), 458.2\left(\mathrm{M}-\mathrm{C}_{16} \mathrm{H}_{30} \mathrm{O}_{5} \mathrm{~N}\right), 442\left(\mathrm{M}-\mathrm{C}_{16} \mathrm{H}_{30} \mathrm{O}_{5} \mathrm{~N}\right), 157.9\left(\mathrm{M}-\mathrm{C}_{32} \mathrm{H}_{38} \mathrm{O}_{10} \mathrm{~N}\right)$.

9-Deoxo-9a-aza-9a-propargyl-9a-homoerythromycin A (3c)

To a well-stirred mixture of $10.0 \mathrm{~g}(13.0 \mathrm{mmol})$ of 2 in $75 \mathrm{ml}$ of $\mathrm{CHCl}_{3}$ and $72 \mathrm{~g}(0.52 \mathrm{~mol})$ suspended anhydrous $\mathrm{K}_{2} \mathrm{CO}_{3}, 62 \mathrm{~g}(0.52 \mathrm{~mol})$ of propargyl bromide was added dropwise over 15 minutes. Ambient temperature stirring was continued for 18 hours. The reaction mixture was filtered and concentrated in vacuo to a foam $(8.5 \mathrm{~g})$. The entire sample was dissolved in $75 \mathrm{ml}$ of anhydrous THF. Triphenylphosphine $(10.5 \mathrm{~g}, 0.04 \mathrm{~mol})$ was added, and the mixture refluxed for 2 hours. Solvent was removed in vacuo, and the crude product was dissolved in $100 \mathrm{ml}$ of EtOAc, which was then layered with an equal volume of $\mathrm{H}_{2} \mathrm{O}$. The $\mathrm{pH}$ was adjusted to $4.0(6 \mathrm{~N} \mathrm{HCl})$. The separated aqueous layer was then stirred with $100 \mathrm{ml}$ of fresh EtOAc while the $\mathrm{pH}$ was adjusted to $10.0(6 \mathrm{~N} \mathrm{NaOH})$. Concentration in vacuo of the organic layer afforded $7.3 \mathrm{~g}$ of semi-purified product. Chromatography of the entire sample on silica gel $\left(430 \mathrm{~g}, 230 \sim 400\right.$ mesh, elution with $\mathrm{CHCl}_{3}-\mathrm{MeOH}-\operatorname{conc} \mathrm{NH}_{4} \mathrm{OH}$, $15: 1: 0.1)$ afforded $1.67 \mathrm{~g}(17 \%)$ of purified product as a colorless amorphous solid.

TLC Rf $0.39\left(\mathrm{CH}_{2} \mathrm{Cl}_{2}\right.$ - MeOH - conc $\left.\mathrm{NH}_{4} \mathrm{OH}, 9: 1: 0.1\right) ;{ }^{13} \mathrm{C}$ NMR Table 1 ; MS $m / z 772.9$ (M, $\left.\mathrm{C}_{40} \mathrm{H}_{72} \mathrm{O}_{12} \mathrm{~N}_{2}\right), 614.4\left(\mathrm{M}-\mathrm{C}_{8} \mathrm{H}_{18} \mathrm{O}_{2} \mathrm{~N}\right), 597.4\left(\mathrm{M}-\mathrm{C}_{8} \mathrm{H}_{17} \mathrm{O}_{3} \mathrm{~N}\right), 456.2\left(\mathrm{M}-\mathrm{C}_{16} \mathrm{H}_{30} \mathrm{O}_{5} \mathrm{~N}\right), 440.3(\mathrm{M}-$ $\left.\mathrm{C}_{18} \mathrm{H}_{30} \mathrm{O}_{8} \mathrm{~N}\right), 158.0\left(\mathrm{M}-\mathrm{C}_{32} \mathrm{H}_{58} \mathrm{O}_{10} \mathrm{~N}\right)$.

9-Deoxo-9a-aza-9a-benzyl-9a-homoerythromycin A (3d)

A reaction mixture consisting of $2.00 \mathrm{~g}(2.6 \mathrm{mmol})$ of $2,18 \mathrm{~g}(0.105 \mathrm{~mol})$ benzyl bromide, and $14 \mathrm{~g}(0.105 \mathrm{~mol})$ of suspended anhydrous $\mathrm{K}_{2} \mathrm{CO}_{3}$ in $20 \mathrm{ml}$ of $\mathrm{CHCl}_{3}$, was stirred under nitrogen at ambient temperature for 18 hours. The mixture was then filtered, combined with $100 \mathrm{ml}$ portions of $\mathrm{CHCl}_{3}$ and $\mathrm{H}_{2} \mathrm{O}$, and the $\mathrm{pH}$ adjusted to $3.0(6 \mathrm{~N} \mathrm{HCl})$. The separated organic layer was extracted with three 50-ml portions of dilute $\mathrm{HCl}(\mathrm{pH} 3)$. The combined aqueous extracts were layered with $100 \mathrm{ml}$ of $\mathrm{CHCl}_{3}$ and the $\mathrm{pH}$ adjusted to $10\left(10 \% \mathrm{~K}_{2} \mathrm{CO}_{3}\right)$. The organic layer was washed with brine, dried $\left(\mathrm{Na}_{2} \mathrm{SO}_{4}\right)$, and concentrated in vacuo to a foam $(0.96 \mathrm{~g})$. The entire sample was dissolved in $30 \mathrm{ml}$ of EtOH and hydrogenated $\left(0.53 \mathrm{~kg} / \mathrm{cm}^{2}\right.$ pressure, $0.5 \mathrm{~g}$ of $5 \%$ palladium-on-carbon $(50 \%$ water-wet by weight)) for 2 hours. Catalyst filtration and solvent removal afforded $0.66 \mathrm{~g}$ of crude product. Chromatography ( $30 \mathrm{~g}$ silica gel, $70 \sim 230 \mathrm{mesh}$, elution with $\mathrm{CHCl}_{3}$ - 2-propanol - conc $\left.\mathrm{NH}_{4} \mathrm{OH}, 9: 1: 0.01\right)$ afforded $116 \mathrm{mg}(5 \%$ yield $)$ of $\mathbf{3 d}$ as a colorless foam.

TLC Rf $0.33\left(\mathrm{CH}_{2} \mathrm{Cl}_{2}-\mathrm{MeOH}-\right.$ conc $\left.\mathrm{NH}_{4} \mathrm{OH}, 9: 1: 0.1\right) ;{ }^{13} \mathrm{C} \mathrm{NMR}\left(100 \mathrm{MHz}, \mathrm{CDCl}_{3}\right) \delta 177.2$, 139.7, 129.4 (2), 127.9 (2) and 126.7 (aromatic carbons), 103.6, 96.1, 85.6, 78.9, 78.0, 77.8, 75.4, 75.0, $74.8,72.7,70.8,69.0,65.9,65.1,58.7,58.1,49.4,45.7,41.6,41.2,40.4$ (2), 35.0, 29.4, 29.2, 25.6, 22.0, $21.8,21.5,21.4,21.2,18.0,16.7,15.2,11.4,10.1,8.4 ; \mathrm{MS} m / z 825\left(\mathrm{M}, \mathrm{C}_{44} \mathrm{H}_{76} \mathrm{O}_{12} \mathrm{~N}_{2}\right), 733.8\left(\mathrm{M}-\mathrm{C}_{7} \mathrm{H}_{7}\right)$, $666.6\left(\mathrm{M}-\mathrm{C}_{8} \mathrm{H}_{18} \mathrm{O}_{2} \mathrm{~N}\right), 508.3\left(\mathrm{M}-\mathrm{C}_{16} \mathrm{H}_{31} \mathrm{O}_{5} \mathrm{~N}\right), 158.0\left(\mathrm{M}-\mathrm{C}_{86} \mathrm{H}_{60} \mathrm{O}_{10} \mathrm{~N}\right)$.

\section{9-Deoxo-9a-aza-9a-cyanomethyl-9a-homoerythromycin A (3e)}

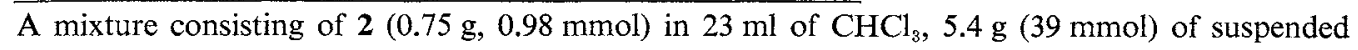


anhydrous $\mathrm{K}_{2} \mathrm{CO}_{3}$, and $4.64 \mathrm{~g}(39 \mathrm{mmol})$ of bromoacetonitrile was stirred for 18 hours at ambient temperature. The reaction was filtered, and the filtrate was concentrated in vacuo to a colorless oil. Trituration with $\mathrm{Et}_{2} \mathrm{O}(350 \mathrm{ml})$ afforded a light yellow granular solid, isolated by filtration $(0.48 \mathrm{~g})$. The entire sample was dissolved in $3 \mathrm{ml}$ of anhydrous THF. Triphenylphosphine $(0.59 \mathrm{~g}, 2.3 \mathrm{mmol})$ was added, and the resulting solution was refluxed for 2 hours. The reaction was filtered and concentrated to an oil, which was dissolved in $40 \mathrm{ml}$ of EtOAc. An equal volume of $\mathrm{H}_{2} \mathrm{O}$ was added and the $\mathrm{pH}$ of the well-stirred mixture was adjusted to $2.0(6 \mathrm{~N} \mathrm{HCl})$. The aqueous extract was separated, layered with $40 \mathrm{ml}$ of fresh EtOAc, and the $\mathrm{pH}$ was adjusted to $9.0(1 \mathrm{~N} \mathrm{NaOH})$. The organic phase was separated, dried $\left(\mathrm{Na}_{2} \mathrm{SO}_{4}\right)$, and concentrated in vacuo to an amorphous solid (0.38 g). Chromatography of the entire sample ( $16 \mathrm{~g}$ silica gel, $32 \sim 63$ mesh, elution with $\mathrm{CH}_{2} \mathrm{Cl}_{2}-\mathrm{MeOH}-$ conc $\mathrm{NH}_{4} \mathrm{OH}$, $15: 1: 0.04)$ afforded $102 \mathrm{mg}(13.5 \%$ yield $)$ of $3 \mathrm{e}$ as a colorless amorphous solid.

TLC Rf $0.61\left(\mathrm{CHCl}_{3}-\mathrm{MeOH}-\right.$ conc $\left.\mathrm{NH}_{4} \mathrm{OH}, 6: 1: 0.1\right) ;{ }^{13} \mathrm{C} \mathrm{NMR}\left(100 \mathrm{MHz}, \mathrm{CDCl}_{3}\right) \delta 178.0$, $116.8(\mathrm{C} \equiv \mathrm{N}), 102.8,95.2,83.7,78.1,77.9,77.7,77.2,75.0,74.4,74.1,72.8,70.8,68.8,65.7,65.5,61.5$, $49.3,44.9,42.5,41.7,40.3$ (2), 37.2, 34.8, 28.8, 26.2, 26.0, 21.5, 21.4, 21.3, 21.1, 18.3, 16.5, 14.8, 11.2, $10.0,9.5 ; \mathrm{MS} m / z 773.5\left(\mathrm{M}, \mathrm{C}_{38} \mathrm{H}_{71} \mathrm{O}_{12} \mathrm{~N}_{3}\right), 615.4160\left(\mathrm{M}-\mathrm{C}_{8} \mathrm{H}_{14} \mathrm{O}_{3}\right), 615.3775\left(\mathrm{M}-\mathrm{C}_{8} \mathrm{H}_{16} \mathrm{O}_{2} \mathrm{~N}\right), 159$ $\left(\mathrm{M}-\mathrm{C}_{31} \mathrm{H}_{56} \mathrm{O}_{9} \mathrm{~N}_{3}\right), 158\left(\mathrm{M}-\mathrm{C}_{31} \mathrm{H}_{55} \mathrm{O}_{10} \mathrm{~N}_{2}\right)$.

\section{9-Deoxo-9a-aza-9a-ethyl-9a-homoerythromycin A (4)}

A solution of $1(2.0 \mathrm{~g}, 2.72 \mathrm{mmol})$ and acetaldehyde $(1.5 \mathrm{ml}, 27 \mathrm{mmol})$ in $20 \mathrm{ml}$ of EtOH and $2.3 \mathrm{ml}$ of $\mathrm{H}_{2} \mathrm{O}$ was hydrogenated $\left(3.5 \mathrm{~kg} / \mathrm{cm}^{2}\right.$ pressure, $2.0 \mathrm{~g}$ of $5 \%$ palladium-on-carbon catalyst $(50 \%$ water-wet by weight)) for 18 hours. The catalyst was filtered, and the filtrate was concentrated in vacuo to a colorless foam. Chromatography on silica gel $\left(30 \mathrm{~g}, 32 \sim 63\right.$ mesh, elution with $\mathrm{CH}_{2} \mathrm{Cl}_{2}$ $\mathrm{MeOH}$ - conc $\left.\mathrm{NH}_{4} \mathrm{OH}, 10: 1: 0.04\right)$ afforded $1.00 \mathrm{~g}(48 \%$ yield) of 4 as a colorless amorphous solid.

TLC Rf $0.30\left(\mathrm{CH}_{2} \mathrm{Cl}_{2}-\mathrm{MeOH}-\right.$ conc $\left.\mathrm{NH}_{4} \mathrm{OH}, 6: 1: 0.1\right) ;{ }^{13} \mathrm{C}$ NMR $\left(100 \mathrm{MHz}, \mathrm{CDCl}_{3}\right) \delta 177.3$, $103.0,95.3,83.8,78.6,78.1,77.7,75.0,74.9,74.1,74.0,72.9,71.0,68.7,65.6,63.9,61.3,49.4,44.9$, 43.4, 42.1, 41.1, $40.4(2), 35.0,29.0,28.4,27.1,22.4,21.6,21.3(2), 18.2,16.7,15.0,12.3,11.3,9.6(2)$; MS $m / z 762.8\left(\mathrm{M}, \mathrm{C}_{39} \mathrm{H}_{74} \mathrm{O}_{12} \mathrm{~N}_{2}\right), 604\left(\mathrm{M}-\mathrm{C}_{8} \mathrm{H}_{18} \mathrm{O}_{2} \mathrm{~N}\right), 446.3140\left(\mathrm{M}-\mathrm{C}_{18} \mathrm{H}_{30} \mathrm{O}_{5} \mathrm{~N}, \mathrm{C}_{23} \mathrm{H}_{44} \mathrm{O}_{7} \mathrm{~N}\right)$, $430.3162\left(\mathrm{M}-\mathrm{C}_{16} \mathrm{H}_{30} \mathrm{O}_{6} \mathrm{~N}, \mathrm{C}_{23} \mathrm{H}_{44} \mathrm{O}_{6} \mathrm{~N}\right), 158\left(\mathrm{M}-\mathrm{C}_{31} \mathrm{H}_{58} \mathrm{O}_{10} \mathrm{~N}\right)$.

\section{9-Deoxo-9a-aza-9a-(n-propyl)-9a-homoerythromycin A (5) (Method A)}

To a well-stirred solution of $5.0 \mathrm{~g}(6.24 \mathrm{mmol})$ of $15 \mathrm{c}$ and $91 \mathrm{~g}(0.31 \mathrm{~mol})$ of tri- $n$-butyltin hydride in $50 \mathrm{ml}$ of xylenes (boiling range $139 \sim 141^{\circ} \mathrm{C}$ ) heated to $125^{\circ} \mathrm{C}$, azobisisobutylnitrile $(5.12 \mathrm{~g}, 31.2$ mmol) suspended in $50 \mathrm{ml}$ of xylene was added dropwise over a period of 1 hour. On completion of the addition, the reaction mixture was maintained at $125^{\circ} \mathrm{C}$ for 45 minutes. EtOAc $(75 \mathrm{ml})$ and $\mathrm{H}_{2} \mathrm{O}$ $(75 \mathrm{ml})$ were added, and the $\mathrm{pH}$ of the aqueous phase was adjusted to $4.5(6 \mathrm{~N} \mathrm{HCl})$. After stirring for 20 minutes the phases were separated, and the organic phase was stirred for 20 minutes with $50 \mathrm{ml}$ of fresh $\mathrm{H}_{2} \mathrm{O}$ at $\mathrm{pH} 4.5$. The two aqueous extracts were combined and washed with EtOAc $(2 \times$ $30 \mathrm{ml}$ ). The aqueous layer was separated, combined with $50 \mathrm{ml}$ of fresh EtOAc, and the $\mathrm{pH}$ was adjusted to $10\left(10 \% \mathrm{~K}_{2} \mathrm{CO}_{3}\right)$. The organic phase was separated and washed first with water, then with brine, and dried (anhydrous $\mathrm{K}_{2} \mathrm{CO}_{3}$ ). Solvent removal in vacuo afforded $3.9 \mathrm{~g}$ of amber foam. Chromatography of $3.2 \mathrm{~g}$ of the crude product $(285 \mathrm{~g}$ of $230 \sim 400$ mesh silica gel; eluting initially with 1 liter of $\mathrm{CHCl}_{3}-\mathrm{MeOH}$ - conc $\mathrm{NH}_{4} \mathrm{OH}, 96: 3.2: 0.3$ and then with $\mathrm{CHCl}_{3}-\mathrm{MeOH}-$ conc $\mathrm{NH}_{4} \mathrm{OH}$, $92: 7.2: 0.72)$ afforded $391 \mathrm{mg}(10 \%$ yield) of 5 as a colorless foam.

TLC Rf $0.30\left(\mathrm{CH}_{2} \mathrm{Cl}_{2}-\mathrm{MeOH}-\right.$ conc $\left.\mathrm{NH}_{4} \mathrm{OH}, 9: 1: 0.1\right) ;{ }^{13} \mathrm{C} \mathrm{NMR}\left(300 \mathrm{MHz}, \mathrm{CDCl}_{3}\right) \delta 177.9$, 103.1, 95.3, 83.8, 78.7, 78.1, 77.8, 77.5, 75.0, 74.1, 74.0, 72.8, 70.9, 68.8, 65.6, 64.7, 61.3, 52.3, 49.4, $44.8,41.9,41.0,40.4(2), 35.0,28.9,28.5,27.1,22.4,21.6,21.5,21.4,20.3,18.3,16.5,15.0,12.1,11.3$, 9.6, 9.5; MS $m / z 776.4\left(\mathrm{M}, \mathrm{C}_{40} \mathrm{H}_{70} \mathrm{O}_{12} \mathrm{~N}_{2}\right), 618.4\left(\mathrm{M}-\mathrm{C}_{8} \mathrm{H}_{10} \mathrm{O}_{2} \mathrm{~N}\right), 460.3\left(\mathrm{M}-\mathrm{C}_{10} \mathrm{H}_{30} \mathrm{O}_{5} \mathrm{~N}\right), 158.1$ $\left(\mathrm{M}-\mathrm{C}_{32} \mathrm{H}_{60} \mathrm{O}_{10} \mathrm{~N}\right)$.

\section{9-Deoxo-9a-aza-9a-( $n$-propyl)-9a-homoerythromycin A (5) (Method B)}

A solution of $0.19 \mathrm{~g}(0.25 \mathrm{mmol})$ of $3 \mathrm{~b}$ in $5 \mathrm{ml}$ of absolute EtOH was hydrogenated $\left(3.5 \mathrm{~kg} / \mathrm{cm}^{2}\right.$ pressure; $10 \%$ palladium-on-carbon catalyst) for 18 hours. The catalyst was filtered, and the filter cake was washed with $10 \mathrm{ml}$ of EtOH. The cake wash solution and filtrate were combined, and then evaporated to a white solid. Chromatography of the entire sample ( $8 \mathrm{~g}$ silica gel, $32 \sim 63 \mathrm{mesh}$, eluting 
initially with $\mathrm{CH}_{2} \mathrm{Cl}_{2}-\mathrm{MeOH}$ - conc $\mathrm{NH}_{4} \mathrm{OH}, 97: 3: 0.04$ ) and then with $\mathrm{CH}_{2} \mathrm{Cl}_{2}-\mathrm{MeOH}$ - conc $\left.\mathrm{NH}_{4} \mathrm{OH}, 95: 5: 0.4\right)$ afforded $37 \mathrm{mg}(19 \%$ yield) of 5 which was identical in all respects to the sample of 5 prepared by Method A.

2'-Acetyl-9-deoxo-9a-aza-9a-methyl-9a-homoerythromycin A (6)

To a solution of $6.4 \mathrm{~g}(8.6 \mathrm{mmol})$ of $3 \mathrm{a}$ in $50 \mathrm{ml}$ of EtOAc was added $1.32 \mathrm{~g}$ (13 mmol) of acetic anhydride. The mixture was stirred at ambient temperature for 18 hours. The reaction was diluted with $50 \mathrm{ml}$ of $\mathrm{H}_{2} \mathrm{O}$, and then stirred for an additional 30 minutes. The $\mathrm{pH}$ of the aqueous layer was then adjusted to $2.5(1 \mathrm{~N} \mathrm{HCl})$, and the organic and aqueous layers were separated. The $\mathrm{pH}$ of the aqueous solution was adjusted to $9.5(1 \mathrm{~N} \mathrm{NaOH})$ and extracted with EtOAc. The pH 9.5 EtOAc extracts were combined, dried (anhydrous $\left.\mathrm{Na}_{2} \mathrm{SO}_{4}\right)$, and evaporated to yield $6.0 \mathrm{~g}(89 \%$ yield) of acetate 6 as a white amorphous foam. This material was used in all further reactions where required. Crystallization $\left(\mathrm{Et}_{2} \mathrm{O}\right)$ afforded acetate 6 as a white solid.

MP $164 \sim 165^{\circ} \mathrm{C} ;{ }^{1} \mathrm{H}$ NMR $\left(250 \mathrm{MHz}, \mathrm{CDCl}_{3}\right) \delta 3.46\left(3 \mathrm{H}, \mathrm{s}, 3^{\prime \prime}-\mathrm{OCH}_{3}\right), 2.30\left(3 \mathrm{H}, \mathrm{s}, 9 \mathrm{a}-\mathrm{CH}_{3}\right)$, $2.25\left(6 \mathrm{H}, \mathrm{s}, 3^{\prime}-\mathrm{N}\left(\mathrm{CH}_{3}\right)_{2}\right), 2.06\left(3 \mathrm{H}, \mathrm{s}, 2^{\prime}-\mathrm{COCH}_{3}\right) ;{ }^{13} \mathrm{C} \mathrm{NMR}\left(250 \mathrm{MHz}, \mathrm{CDCl}_{3}\right) \delta 178.7,169.9,100.7$, $94.7,83.2,78.2,77.8,77.6,74.3,74.0,73.7,73.1,71.9,70.2,68.3,65.7,63.8,62.4,49.4,45.2,42.1,41.9$, $40.8,36.3,34.8,30.6,27.5,26.7,22.0,21.7,21.5,21.3,21.2,18.3,16.2,14.8,11.3,8.9,7.4$; MS $\mathrm{m} / \mathrm{z} 791$ $\left(\mathrm{M}, \mathrm{C}_{40} \mathrm{H}_{74} \mathrm{O}_{13} \mathrm{~N}_{2}\right), 615\left(\mathrm{M}-\mathrm{C}_{8} \mathrm{H}_{15} \mathrm{O}_{4}\right), 590\left(\mathrm{M}-\mathrm{C}_{10} \mathrm{H}_{18} \mathrm{O}_{2} \mathrm{~N}\right), 415\left(\mathrm{M}-\mathrm{C}_{18} \mathrm{H}_{33} \mathrm{O}_{6} \mathrm{~N}\right), 200(\mathrm{M}-$ $\left.\mathrm{C}_{30} \mathrm{H}_{50} \mathrm{O}_{10} \mathrm{~N}\right), 159\left(\mathrm{M}-\mathrm{C}_{32} \mathrm{H}_{50} \mathrm{O}_{8} \mathrm{~N}_{2}\right), 127\left(\mathrm{M}-\mathrm{C}_{33} \mathrm{H}_{62} \mathrm{O}_{10} \mathrm{~N}\right)_{2}$.

\section{2'-Acetyl-4"-dehydro-4"'-oxo-9-deoxo-9a-aza-9a-methyl-9a-homoerythromycin A (7)}

A mixture of $7.5 \mathrm{~g}(9.5 \mathrm{mmol})$ of acetate $6,6.7 \mathrm{ml}(95 \mathrm{mmol})$ of dimethyl sulfoxide, and $5.5 \mathrm{~g}$ (28 mmol) of 1-(3-dimethylaminopropyl)-3-ethylcarbodiimide were combined at ambient temperature in $75 \mathrm{ml}$ of $\mathrm{CH}_{2} \mathrm{Cl}_{2}$ under a nitrogen atmosphere. To this solution was added portionwise $5.5 \mathrm{~g}$ (28 $\mathrm{mmol}$ ) of pyridinium trifluoroacetate over a 5 -minute period. The reaction mixture was stirred at ambient temperature for 2 hours. To this solution was added an equal volume of $\mathrm{H}_{2} \mathrm{O}$, and the aqueous layer was extracted with EtOAc sequentially at $\mathrm{pH} 4.0,6.5$, and 9.5. The $\mathrm{pH} 9.5$ EtOAc extracts were combined, dried (anhydrous $\mathrm{Na}_{2} \mathrm{SO}_{4}$ ), and evaporated to yield $6.2 \mathrm{~g}(82 \%$ yield) of ketone 7 as a white amorphous solid.

TLC Rf 0.6 (EtOAc - acetone - conc $\left.\mathrm{NH}_{4} \mathrm{OH}, 10: 1: 0.1\right) ;{ }^{1} \mathrm{H}$ NMR $\left(250 \mathrm{MHz}, \mathrm{CDCl}_{3}\right) \delta 3.30$ $\left(3 \mathrm{H}, \mathrm{s}, 3^{\prime \prime}-\mathrm{OCH}_{3}\right), 2.24\left(9 \mathrm{H}, \mathrm{s}, 9 \mathrm{a}-\mathrm{CH}_{3}, 3^{\prime}-\mathrm{N}\left(\mathrm{CH}_{3}\right)_{2}\right), 2.00\left(3 \mathrm{H}, \mathrm{s}, 2^{\prime}-\mathrm{COCH}_{3}\right) ;{ }^{13} \mathrm{C} \mathrm{NMR}(250 \mathrm{MHz}$, $\left.\mathrm{CDCl}_{3}\right) \delta 211.1\left(\mathrm{C}-4^{\prime \prime}, \mathrm{C}=\mathrm{O}\right), 179.9,169.5,100.5,95.6,83.0,78.1,77.6,74.5,74.1,73.5,72.0,71.5(2)$, $70.0,68.5,63.1,62.1,51.1,44.5,41.7,40.5(2), 40.1,37.2,36.4,30.5,27.0,26.5,21.7,21.4,21.1,21.0$, 20.7, 16.3, 16.2, 15.0, 11.1, 8.9, 7.3; MS $m / z 789.7\left(\mathrm{M}+1, \mathrm{C}_{40} \mathrm{H}_{73} \mathrm{O}_{13} \mathrm{~N}_{2}\right), 673.5\left(\mathrm{M}-\mathrm{C}_{6} \mathrm{H}_{11} \mathrm{O}_{2}\right), 588.4$ $\left(\mathrm{M}-\mathrm{C}_{10} \mathrm{H}_{18} \mathrm{O}_{2} \mathrm{~N}\right), 200.1\left(\mathrm{M}-\mathrm{C}_{30} \mathrm{H}_{56} \mathrm{O}_{10} \mathrm{~N}\right), 157.1\left(\mathrm{M}-\mathrm{C}_{32} \mathrm{H}_{59} \mathrm{O}_{9} \mathrm{~N}_{2}\right)$.

\section{4"-Dehydro-4"-oxo-9-deoxo-9a-aza-9a-methyl-9a-homoerythromycin A (8)}

A solution of $0.93 \mathrm{~g}(1.2 \mathrm{mmol})$ of ketone 7 in $50 \mathrm{ml}$ of $\mathrm{MeOH}$ was stirred at ambient temperature for 20 hours. Evaporation of the solvent yielded $0.82 \mathrm{~g}$ ( $94 \%$ yield) of ketone 8 as a white crystalline solid.

MP $133 \sim 134^{\circ} \mathrm{C}$; TLC Rf $0.52\left(\mathrm{CHCl}_{3}-\mathrm{MeOH}-\right.$ conc $\left.\mathrm{NH}_{4} \mathrm{OH}, 5: 1: 0.2\right)$; ${ }^{1} \mathrm{H}$ NMR $(250 \mathrm{MHz}$, $\left.\mathrm{CDCl}_{3}\right) \delta 3.33\left(3 \mathrm{H}, \mathrm{s}, 3^{\prime \prime}-\mathrm{OCH}_{3}\right), 2.38\left(3 \mathrm{H}, \mathrm{s}, 9 \mathrm{a}-\mathrm{CH}_{3}\right), 2.29\left(6 \mathrm{H}, \mathrm{s}, 3^{\prime}-\mathrm{N}\left(\mathrm{CH}_{3}\right)_{2}\right) ;{ }^{13} \mathrm{C} \mathrm{NMR}(250 \mathrm{MHz}$, $\mathrm{CDCl}_{3}$ ) $\delta 208.1\left(\mathrm{C}-4^{\prime \prime}, \mathrm{C}=\mathrm{O}\right), 178.4,103.7,96.2,84.5,78.5,77.8,77.2,74.9,74.4,73.6,72.3,71.0$, $70.3,69.3,65.4,62.2,51.3,44.6,42.2,40.4(2), 40.1,36.8,36.6,29.1,27.0,26.6,21.8,21.4,21.0(2)$, $16.3,16.2,15.3,15.2,11.2,9.2,7.5 ; \mathrm{MS} m / z 746.4\left(\mathrm{M}, \mathrm{C}_{38} \mathrm{H}_{70} \mathrm{O}_{12} \mathrm{~N}_{2}\right), 588.4\left(\mathrm{M}-\mathrm{C}_{8} \mathrm{H}_{16} \mathrm{O}_{2} \mathrm{~N}\right), 573.4$ $\left(\mathrm{M}-\mathrm{C}_{8} \mathrm{H}_{15} \mathrm{O}_{4}\right), 158.1\left(\mathrm{M}-\mathrm{C}_{30} \mathrm{H}_{58} \mathrm{O}_{10} \mathrm{~N}\right)$.

\section{4"-epi-9-Deoxo-9a-aza-9a-methyl-9a-homoerythromycin A (9)}

A solution of $0.30 \mathrm{~g}(0.38 \mathrm{mmol})$ of ketone 8 in $10 \mathrm{ml}$ of $E$ tOH was hydrogenated $\left(3.5 \mathrm{~kg} / \mathrm{cm}^{2}\right.$ pressure, $50 \mathrm{mg}$ of Raney nickel catalyst) for 18 hours. An additional $50 \mathrm{mg}$ of Raney nickel was added to the mixture, and hydrogenation was continued for an additional 18 hours. The reaction mixture was filtered, and the filtrate evaporated. The residue was dissolved in $20 \mathrm{ml}$ of EtOAc, and then stirred with $20 \mathrm{ml}$ of $\mathrm{H}_{2} \mathrm{O}$ while the $\mathrm{pH}$ was adjusted to $2.5(2 \mathrm{~N} \mathrm{HCl})$. The aqueous layers was

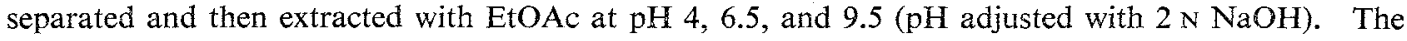


$\mathrm{pH}$ 9.5 EtOAc extracts were combined, dried (anhydrous $\mathrm{Na}_{2} \mathrm{SO}_{4}$ ), and evaporated to yield $0.17 \mathrm{~g}$ (57\% yield) of the $\mathrm{C}-4$ " epi-alcohol 9 as a white amorphous solid.

TLC Rf $0.61\left(\mathrm{CHCl}_{3}\right.$ - acetone - conc $\left.\mathrm{NH}_{4} \mathrm{OH}, 6: 6: 0.4\right) ;{ }^{1} \mathrm{H}$ NMR $\left(250 \mathrm{MHz}, \mathrm{CDCl}_{3}\right) \delta 3.32$ $\left(3 \mathrm{H}, \mathrm{s}, 3^{\prime \prime}-\mathrm{OCH}_{3}\right), 2.31\left(3 \mathrm{H}, \mathrm{s}, 9 \mathrm{a}-\mathrm{CH}_{3}\right), 2.29\left(6 \mathrm{H}, \mathrm{s}, 3^{\prime}-\mathrm{N}\left(\mathrm{CH}_{3}\right)_{2}\right) ;{ }^{13} \mathrm{C}$ NMR Table $1 ; \mathrm{MS} m / z 748.7$ $\left(\mathrm{M}, \mathrm{C}_{38} \mathrm{H}_{72} \mathrm{O}_{12} \mathrm{~N}_{2}\right), 590.5\left(\mathrm{M}-\mathrm{C}_{8} \mathrm{H}_{16} \mathrm{O}_{2} \mathrm{~N}\right), 573.5\left(\mathrm{M}-\mathrm{C}_{8} \mathrm{H}_{17} \mathrm{O}_{3} \mathrm{~N}\right), 432.4\left(\mathrm{M}-\mathrm{C}_{16} \mathrm{H}_{30} \mathrm{O}_{5} \mathrm{~N}\right), 416.4$ $\left(\mathrm{M}-\mathrm{C}_{16} \mathrm{H}_{30} \mathrm{O}_{8} \mathrm{~N}\right), 158\left(\mathrm{M}-\mathrm{C}_{30} \mathrm{H}_{56} \mathrm{O}_{10} \mathrm{~N}\right)$.

4"-Deoxo-4"-oximino-9-deoxo-9a-aza-9a-methyl-9a-homoerythromycin A (10)

A mixture of $0.30 \mathrm{~g}(0.4 \mathrm{mmol})$ of ketone 8 dissolved in $15 \mathrm{ml}$ of $\mathrm{MeOH}$, and $0.14 \mathrm{~g}(0.20 \mathrm{mmol})$ of hydroxylamine hydrochloride was stirred at ambient temperature for 72 hours. The solvent was removed in vacuo, and the residue was dissolved in $30 \mathrm{ml}$ of EtOAc $-\mathrm{H}_{2} \mathrm{O}(1: 1)$ mixture. The pH of the aqueous phase was adjusted to $9.5(1 \mathrm{~N} \mathrm{NaOH})$. After stirring well, the EtOAc layer was separated from the aqueous layer, dried (anhydrous $\left.\mathrm{Na}_{2} \mathrm{SO}_{4}\right)$, and evaporated to yield $0.25 \mathrm{~g}(81 \%$ yield) of oxime $\mathbf{1 0}$ as a colorless amorphous solid.

TLC Rf 0.70 (acetone - $\mathrm{CHCl}_{3}$ - conc $\left.\mathrm{NH}_{4} \mathrm{OH}, 8: 4: 0.2\right) ;{ }^{1} \mathrm{H}$ NMR $\left(250 \mathrm{MHz}, \mathrm{CDCl}_{3}\right) \delta 3.20$ $\left(3 \mathrm{H}, \mathrm{s}, 3^{\prime \prime}-\mathrm{OCH}_{3}\right), 2.31\left(3 \mathrm{H}, \mathrm{s}, 9 \mathrm{a}-\mathrm{CH}_{3}\right), 2.24\left(6 \mathrm{H}, \mathrm{s}, 3^{\prime}-\mathrm{N}\left(\mathrm{CH}_{3}\right)_{2}\right) ;{ }^{13} \mathrm{C} \mathrm{NMR}\left(250 \mathrm{MHz}, \mathrm{CDCl}_{3}\right) \delta 176.6$, $157.8\left({\left.\mathrm{C}-4^{\prime \prime}\right)}^{\prime}, 101.9,94.7,84.7,82.2,77.3,75.2,74.6,74.2,73.4,71.2,70.7,68.6,66.2,65.9,62.5,50.1\right.$, $44.2,42.0,40.4(2), 39.8,37.6,36.2,29.7,28.2,26.6,26.5,21.5,21.4,21.1,16.8,16.3,16.0,11.0,9.1$, 7.2; MS $m / z 761.7\left(\mathrm{M}, \mathrm{C}_{38} \mathrm{H}_{71} \mathrm{O}_{12} \mathrm{~N}_{3}\right), 603.5\left(\mathrm{M}-\mathrm{C}_{8} \mathrm{H}_{16} \mathrm{O}_{2} \mathrm{~N}\right), 573.5\left(\mathrm{M}-\mathrm{C}_{8} \mathrm{H}_{14} \mathrm{O}_{4} \mathrm{~N}\right), 413.4(\mathrm{M}-$ $\left.\mathrm{C}_{16} \mathrm{H}_{32} \mathrm{O}_{6} \mathrm{~N}_{2}\right), 158\left(\mathrm{M}-\mathrm{C}_{30} \mathrm{H}_{57} \mathrm{O}_{8} \mathrm{~N}_{2}\right)$.

4"-Deoxo-4"- $\alpha$-amino-9-deoxo-9a-aza-9a-methyl-9a-homoerythromycin A (11)

A solution of $0.8 \mathrm{~g}(1.05 \mathrm{mmol})$ of oxime 10 in $20 \mathrm{ml}$ of $\mathrm{EtOH}$ was hydrogenated $\left(3.5 \mathrm{~kg} / \mathrm{cm}^{2}\right.$ pressure; $1.0 \mathrm{~g}$ of Raney nickel catalyst) at ambient temperature for 18 hours. Chromatography on silica gel using $\mathrm{CHCl}_{3}$ - acetone $(1: 1)$ as eluant afforded $0.25 \mathrm{~g}$ (32\% yield) of amine 11 as a colorless amorphous solid.

TLC Rf $0.33\left(\mathrm{CHCl}_{3}\right.$ - acetone - conc $\left.\mathrm{NH}_{4} \mathrm{OH}, 3: 9: 0.4\right) ;{ }^{1} \mathrm{H} \mathrm{NMR}\left(250 \mathrm{MHz}, \mathrm{CDCl}_{3}\right) \delta 3.38$ $\left(3 \mathrm{H}, \mathrm{s}, 3^{\prime \prime}-\mathrm{OCH}_{3}\right), 2.31\left(3 \mathrm{H}, \mathrm{s}, 9 \mathrm{a}-\mathrm{CH}_{3}\right), 2.28\left(6 \mathrm{H}, \mathrm{s}, 3^{\prime}-\mathrm{N}\left(\mathrm{CH}_{3}\right)_{2}\right) ;{ }^{13} \mathrm{C}$ NMR Table $1 ; \mathrm{MS} m / z 748$ $\left(\mathrm{M}, \mathrm{C}_{38} \mathrm{H}_{73} \mathrm{O}_{11} \mathrm{~N}_{3}\right), 589\left(\mathrm{M}-\mathrm{C}_{8} \mathrm{H}_{16} \mathrm{O}_{2} \mathrm{~N}\right), 432.3\left(\mathrm{M}-\mathrm{C}_{16} \mathrm{H}_{31} \mathrm{O}_{4} \mathrm{~N}_{2}\right), 158\left(\mathrm{M}-\mathrm{C}_{30} \mathrm{H}_{57} \mathrm{O}_{8} \mathrm{~N}_{2}\right)$.

\section{9-Deoxo-9a-aza-9a-( $\beta$-cyanoethyl)-9a-homoerythromycin A (13)}

A solution of $1(1.0 \mathrm{~g}, 1.36 \mathrm{mmol})$ in $10.0 \mathrm{ml}$ of acrylonitrile was refluxed for 6 hours and then stirred overnight at ambient temperature. The mixture was concentrated in vacuo to a tan foam. Chromatography ( $40 \mathrm{~g}$ silica gel, $70 \sim 230$ mesh, elution with $\mathrm{CH}_{2} \mathrm{Cl}_{2}-\mathrm{MeOH}-\operatorname{conc} \mathrm{NH}_{4} \mathrm{OH}, 10: 1$ : 0.01 ) afforded $605 \mathrm{mg}$ ( $56 \%$ yield) of 13 as a colorless foam.

TLC Rf $0.57\left(\mathrm{CH}_{2} \mathrm{Cl}_{2}-\mathrm{MeOH}-\right.$ conc $\left.\mathrm{NH}_{4} \mathrm{OH}, 6: 1: 0.01\right) ;{ }^{13} \mathrm{C} \mathrm{NMR}\left(300 \mathrm{MHz}, \mathrm{CDCl}_{3}\right) \delta 177.6$, $118.9(\mathrm{C} \equiv \mathrm{N}), 103.0,95.9,84.4,78.0,77.8,77.1,75.8,75.1,74.7,74.4,72.7,70.8,68.8,65.7,65.3,60.2$, $49.3,47.6,45.1,40.7,40.6,40.3(2), 35.0,29.1,28.9,26.2,22.1,21.5,21.4,21.3,18.3,17.3,16.6,15.4$, 11.2, 9.7, 8.9; MS $m / z 789.4\left(\mathrm{M}+1, \mathrm{C}_{40} \mathrm{H}_{73} \mathrm{O}_{12} \mathrm{~N}_{3}\right), 629.7\left(\mathrm{M}-\mathrm{C}_{8} \mathrm{H}_{16} \mathrm{O}_{2} \mathrm{~N}\right), 471.4\left(\mathrm{M}-\mathrm{C}_{10} \mathrm{H}_{30} \mathrm{O}_{5} \mathrm{~N}\right)$, $455.4\left(\mathrm{M}-\mathrm{C}_{18} \mathrm{H}_{30} \mathrm{O}_{6} \mathrm{~N}\right), 158.2\left(\mathrm{M}-\mathrm{C}_{32} \mathrm{H}_{57} \mathrm{O}_{10} \mathrm{~N}_{2}\right)$.

4"-epi-9-Deoxo-9a-aza-9a-( $\beta$-cyanoethyl)-9a-homoerythromycin A (14)

A solution of $12(11.6 \mathrm{~g}, 15.8 \mathrm{mmol})$ in $100 \mathrm{ml}$ of acrylonitrile was refluxed for 19 hours, and then concentrated in vacuo to afford $14(12.8 \mathrm{~g}, 98 \%$ yield) as an ivory foam. TLC inspection $\left(\mathrm{CH}_{2} \mathrm{Cl}_{2}-\mathrm{MeOH}\right.$ - conc $\left.\mathrm{NH}_{4} \mathrm{OH}, 6: 1: 0.1\right)$ showed a single (less polar, $\mathrm{Rf} 0.51$ ) product.

${ }^{13} \mathrm{C}$ NMR $\left(300 \mathrm{MHz}, \mathrm{CDCl}_{3}\right) \delta 177.8,119.0,102.6,96.1,84.1,78.5,77.1,76.7,74.7,74.4,73.9$, $73.8,70.9,68.4,64.8,64.6,63.5,60.8,49.1,47.0,45.3,41.4,41.1,40.2(2), 29.4,29.2,28.4,26.1,22.2$, $21.5,21.3,21.2,17.2,16.8,16.6,15.0,11.1,9.5,8.8 ; \mathrm{MS} m / z 788.3\left(\mathrm{M}^{+}, \mathrm{C}_{40} \mathrm{H}_{73} \mathrm{O}_{12} \mathrm{~N}_{3}\right), 629.6(\mathrm{M}-$ $\left.\mathrm{C}_{8} \mathrm{H}_{16} \mathrm{O}_{2} \mathrm{~N}\right), 471.3\left(\mathrm{M}-\mathrm{C}_{16} \mathrm{H}_{30} \mathrm{O}_{5} \mathrm{~N}\right), 455.4\left(\mathrm{M}-\mathrm{C}_{10} \mathrm{H}_{30} \mathrm{O}_{6} \mathrm{~N}\right), 158.1\left(\mathrm{M}-\mathrm{C}_{32} \mathrm{H}_{57} \mathrm{O}_{10} \mathrm{~N}_{2}\right)$.

9-Deoxo-9a-aza-9a-( $\gamma$-aminopropyl)-9a-homoerythromycin A (15a)

A solution of $47 \mathrm{~g}(59.6 \mathrm{mmol})$ of 13 in $520 \mathrm{ml}$ of EtOH was hydrogenated $\left(3.5 \mathrm{~kg} / \mathrm{cm}^{2}\right.$ pressure) using $47 \mathrm{~g}$ of Raney nickel catalyst ( $50 \%$ water-wet by weight) for 3 hours. The mixture was then charged with $25 \mathrm{~g}$ of fresh catalyst, and hydrogenation $\left(3.5 \mathrm{~kg} / \mathrm{cm}^{2}\right.$ pressure) was continued for an 
additional 1.5 hours. Catalyst filtration and solvent removal in vacuo afforded a colorless foam. The crude product in $600 \mathrm{ml}$ of EtOAc was stirred with $800 \mathrm{ml}$ of $\mathrm{H}_{2} \mathrm{O}$ while the $\mathrm{pH}$ was adjusted to $9.5(6 \mathrm{~N} \mathrm{NaOH})$. The separated organic phase was dried $\left(\mathrm{Na}_{2} \mathrm{SO}_{4}\right)$ and concentrated to a foam. Chromatography ( $800 \mathrm{~g}$ silica gel, $70 \sim 230$ mesh, elution with $\mathrm{CHCl}_{3}-\mathrm{MeOH}$ - conc $\mathrm{NH}_{4} \mathrm{OH}, 6: 1$ : 0.05 ) afforded $14.7 \mathrm{~g}$ ( $31 \%$ yield) of 15a. Crystallization of a $1.1 \mathrm{~g}$ sample from $\mathrm{Et}_{2} \mathrm{O}$ gave $545 \mathrm{mg}$ of colorless crystals.

MP $180 \sim 183^{\circ} \mathrm{C}$; TLC Rf $0.15\left(\mathrm{CHCl}_{3}-\mathrm{MeOH}-\right.$ conc $\left.\mathrm{NH}_{4} \mathrm{OH}, 6: 1: 0.05\right) ;{ }^{13} \mathrm{C}$ NMR Table 1 ; MS $m / z 792.0\left(\mathrm{M}, \mathrm{C}_{40} \mathrm{H}_{77} \mathrm{O}_{12} \mathrm{~N}_{3}\right), 633.6\left(\mathrm{M}-\mathrm{C}_{8} \mathrm{H}_{16} \mathrm{O}_{2} \mathrm{~N}\right), 475.3\left(\mathrm{M}-\mathrm{C}_{16} \mathrm{H}_{30} \mathrm{O}_{5} \mathrm{~N}\right), 157.9(\mathrm{M}-$ $\mathrm{C}_{32} \mathrm{H}_{61} \mathrm{O}_{10} \mathrm{~N}_{2}$ ).

\section{9-Deoxo-9a-( $\gamma$-formamidopropyl)-9a-aza-9a-homoerythromycin A (15b)}

To a stirred solution of $3.0 \mathrm{~g}(3.8 \mathrm{mmol})$ of $15 \mathrm{a}$ in $25 \mathrm{ml}$ of $\mathrm{CH}_{2} \mathrm{Cl}_{2}$ cooled to $5^{\circ} \mathrm{C}, 370 \mathrm{mg}(4.2$ mmol) of acetic-formic anhydride in $5 \mathrm{ml}$ of $\mathrm{CH}_{2} \mathrm{Cl}_{2}$ was added dropwise over 5 minutes. The reaction was then stirred at ambient temperature for 1 hour. After extraction with an equal volume of $10 \%$ aqueous $\mathrm{K}_{2} \mathrm{CO}_{3}$, the organic phase was separated, washed with brine, dried $\left(\mathrm{Na}_{2} \mathrm{SO}_{4}\right)$ and concentrated in vacuo to afford $15 \mathrm{~b}(3.1 \mathrm{~g}, 100 \%$ yield) as a colorless foam.

${ }^{1} \mathrm{H}$ NMR $\left(60 \mathrm{MHz}, \mathrm{CDCl}_{3}\right) \delta 8.15(1 \mathrm{H}$, br s, $H \mathrm{CONH}), 6.76(1 \mathrm{H}$, br m, HCONH$), 3.28(3 \mathrm{H}, \mathrm{s}$, $\left.3^{\prime \prime}-\mathrm{OCH}_{3}\right), 2.25\left(9 \mathrm{H}\right.$, two overlapping singlets, $9 \mathrm{a}-\mathrm{CH}_{3}$ and $\left.3^{\prime}-\mathrm{N}\left(\mathrm{CH}_{3}\right)_{2}\right) ; \mathrm{MS} m / z 819.5(\mathrm{M}$, $\left.\mathrm{C}_{41} \mathrm{H}_{77} \mathrm{O}_{13} \mathrm{~N}_{3}\right), 645.5\left(\mathrm{M}-\mathrm{C}_{8} \mathrm{H}_{16} \mathrm{O}_{3} \mathrm{~N}\right), 503.4\left(\mathrm{M}-\mathrm{C}_{16} \mathrm{H}_{30} \mathrm{O}_{5} \mathrm{~N}\right), 487.2\left(\mathrm{M}-\mathrm{C}_{16} \mathrm{H}_{30} \mathrm{O}_{8} \mathrm{~N}\right), 158.1(\mathrm{M}-$ $\mathrm{C}_{33} \mathrm{H}_{61} \mathrm{O}_{11} \mathrm{~N}_{2}$ ).

\section{9-Deoxo-9a-( $\gamma$-isonitrilopropyl)-9a-aza-9a-homoerythromycin A (15c)}

To a stirred solution of $4.6 \mathrm{~g}(5.6 \mathrm{mmol})$ of $15 \mathrm{~b}$ in $30 \mathrm{ml}$ of pyridine cooled to $5^{\circ} \mathrm{C}$, a solution of $2.7 \mathrm{~g}(14 \mathrm{mmol})$ of $p$-toluenesulfonyl chloride in $10 \mathrm{ml}$ of pyridine was added dorpwise over 10 minutes. The reaction was stirred for 1 hour at ambient temperature and then concentrated to dryness in vacuo. The residue was dissolved in $150 \mathrm{ml}$ of $\mathrm{CH}_{2} \mathrm{Cl}_{2}$. An equal volume of $\mathrm{H}_{2} \mathrm{O}$ was added, and the $\mathrm{pH}$ was adjusted to $10\left(10 \% \mathrm{~K}_{2} \mathrm{CO}_{3}\right)$. The organic phase was separated, washed with $\mathrm{H}_{2} \mathrm{O}(2 \times 100 \mathrm{ml})$ and brine $(100 \mathrm{ml})$, dried (anhydrous $\left.\mathrm{K}_{2} \mathrm{CO}_{3}\right)$, and concentrated in vacuo to afford $15 \mathrm{c}(5.0 \mathrm{~g}, 90 \%$ yield) as an amber foam.

IR $\nu_{\max }\left(\mathrm{CCl}_{4}\right) \mathrm{cm}^{-1} 2140(\mathrm{~N} \equiv \mathrm{C}), 1725(\mathrm{~s}, \mathrm{C}=\mathrm{O}) ; \mathrm{MS} \mathrm{m} / z 802.0\left(\mathrm{M}, \mathrm{C}_{41} \mathrm{H}_{75} \mathrm{O}_{12} \mathrm{~N}_{3}\right), 643.5(\mathrm{M}-$ $\left.\mathrm{C}_{8} \mathrm{H}_{18} \mathrm{O}_{2} \mathrm{~N}\right), 485.3\left(\mathrm{M}-\mathrm{C}_{18} \mathrm{H}_{30} \mathrm{O}_{5} \mathrm{~N}\right), 158.0\left(\mathrm{M}-\mathrm{C}_{33} \mathrm{H}_{58} \mathrm{O}_{10} \mathrm{~N}_{2}\right)$.

\section{4"-epi-9-Deoxo-9a-aza-9a-( $\gamma$-aminopropyl)-9a-homoerythromycin A (16)}

A solution of $12.8 \mathrm{~g}$ (16.2 mmol) of 14 in $250 \mathrm{ml}$ of EtOH was combined with $12.8 \mathrm{~g}$ of Raney nickel catalyst ( $50 \%$ water-wet by weight) and hydrogenated $\left(3.5 \mathrm{~kg} / \mathrm{cm}^{2}\right.$ pressure) for 19 hours. The crude product obtained after catalyst filtration and solvent removal in vacuo was dissolved in $100 \mathrm{ml}$ of $\mathrm{CH}_{2} \mathrm{Cl}_{2}$. After extraction with an equal volume of saturated $\mathrm{NaHCO}_{3}$, the separated organic phase was dried $\left(\mathrm{Na}_{2} \mathrm{SO}_{4}\right)$, and concentrated in vacuo to an ivory foam $(10.5 \mathrm{~g})$. Crystallization from warm $\mathrm{Et}_{2} \mathrm{O}$ yielded $4.0 \mathrm{~g}$ ( $31 \%$ yield) of colorless crystals.

MP $135^{\circ} \mathrm{C}$; TLC Rf $0.13\left(\mathrm{CHCl}_{3}-\mathrm{MeOH}-\right.$ conc $\left.\mathrm{NH}_{4} \mathrm{OH}, 6: 1: 0.1\right) ;{ }^{13} \mathrm{C} \mathrm{NMR}\left(100 \mathrm{MHz}, \mathrm{CDCl}_{3}\right)$ $\delta 177.1,102.2,95.8,83.4,78.4,77.4,77.1,75.8,74.6,74.1,74.0,71.0,68.4,65.7,65.2,63.8,63.2,58.6$, $49.1,48.3,45.0,41.2,40.7,40.3(2), 40.0,29.5,29.0$ (2), 26.0, 23.5, 21.6, 21.4, 21.2, 17.4, 16.5, 15.2, 11.0, 9.6, 6.9; MS $m / z$ 792.1 (M, $\left.\mathrm{C}_{40} \mathrm{H}_{77} \mathrm{O}_{12} \mathrm{~N}_{3}\right), 633.6\left(\mathrm{M}-\mathrm{C}_{8} \mathrm{H}_{16} \mathrm{O}_{2} \mathrm{~N}\right), 475.3\left(\mathrm{M}-\mathrm{C}_{16} \mathrm{H}_{30} \mathrm{O}_{5} \mathrm{~N}\right), 158.0$ $\left(\mathrm{M}-\mathrm{C}_{32} \mathrm{H}_{61} \mathrm{O}_{10} \mathrm{~N}_{2}\right)$.

\section{9,11-Deoxo-9a-aza-[11- $\beta, 9 \mathrm{a}$-(epoxypropano)]-9a-homoerythromycin A (17)}

To a solution of $15 \mathrm{a}(6.24 \mathrm{~g}, 7.90 \mathrm{mmol})$ in $128 \mathrm{ml}$ of $\mathrm{CHCl}_{3}, 1.01 \mathrm{~g}(1.16 \mathrm{ml}, 8.63 \mathrm{mmol})$ of isoamyl nitrite and $0.92 \mathrm{ml}(0.97 \mathrm{~g}, 16.2 \mathrm{mmol})$ of glacial acetic acid were added, and the mixture was vigorously refluxed for 1 hour. The mixture was stirred with $150 \mathrm{ml}$ of $\mathrm{H}_{2} \mathrm{O}$, and the $\mathrm{pH}$ was adjusted to 8.0 (saturated $\mathrm{NaHCO}_{3}$ ). The separated organic phase was washed with an equal volume of $\mathrm{H}_{2} \mathrm{O}$, dried $\left(\mathrm{Na}_{2} \mathrm{SO}_{4}\right)$, and concentrated in vacuo to a yellow foam. Formamide-treated silica gel was prepared by thoroughly mixing $360 \mathrm{ml}$ of formamide, 1.8 liters of acetone, and $900 \mathrm{~g}$ of silica gel (230 $400 \mathrm{mesh}$ ) and then removing solvent in vacuo on a rotary evaporator until a free-flowing powder was obtained. Chromatography of the crude product $(5.8 \mathrm{~g})$ on $900 \mathrm{~g}$ of formamide-impregnated silica 
gel - eluting first with (2 liters) $\mathrm{CHCl}_{3}$ - hexane $(7: 3)$, and then with $\mathrm{CHCl}_{3}$ - hexane $(8: 3)$ - afforded $17(0.79 \mathrm{~g}, 13 \%$ yield $)$ as a colorless amorphous solid.

TLC Rf $0.36\left(\mathrm{CH}_{2} \mathrm{Cl}_{2}-\mathrm{MeOH}\right.$ - conc $\left.\mathrm{NH}_{4} \mathrm{OH}, 9: 1: 0.1\right) ;{ }^{13} \mathrm{C}$ NMR $\left(100 \mathrm{MHz}, \mathrm{CDCl}_{3}\right) \delta 176.1$, 103.0, 96.1, 84.3, 80.42, 80.21, 78.0, 77.7, 74.1, 73.5, 72.7, 71.0, 70.9, 68.5, 67.2, 65.6, 65.4, 62.8, 49.3, $47.2,44.9,42.3,40.3$ (2), 39.8, 35.3, 29.0, 26.9 (2), 21.8, 21.5, 21.4, 21.2, 20.8, 18.5, 17.0, 16.2, 10.7, 9.9, 6.6; MS $m / z 775\left(\mathrm{M}, \mathrm{C}_{40} \mathrm{H}_{74} \mathrm{O}_{12} \mathrm{~N}_{2}\right), 617\left(\mathrm{M}-\mathrm{C}_{8} \mathrm{H}_{18} \mathrm{O}_{2} \mathrm{~N}\right), 458.3045\left(\mathrm{M}-\mathrm{C}_{16} \mathrm{H}_{30} \mathrm{O}_{5} \mathrm{~N}, \mathrm{C}_{24} \mathrm{H}_{44} \mathrm{O}_{7} \mathrm{~N}\right)$, $442.3134\left(\mathrm{M}-\mathrm{C}_{10} \mathrm{H}_{30} \mathrm{O}_{6} \mathrm{~N}, \mathrm{C}_{24} \mathrm{H}_{44} \mathrm{O}_{6} \mathrm{~N}\right), 158\left(\mathrm{M}-\mathrm{C}_{32} \mathrm{H}_{58} \mathrm{O}_{10} \mathrm{~N}\right)$.

\section{4"-epi-9,11-Deoxo-9a-aza-[11- $\beta, 9 \mathrm{a}-($ epoxypropano)]-9a-homoerythromycin A (18)}

To a solution of $16(3.37 \mathrm{~g}, 4.3 \mathrm{mmol})$ in $20 \mathrm{ml}$ of $\mathrm{CHCl}_{3}, 0.66 \mathrm{ml}(4.9 \mathrm{mmol})$ of isoamyl nitrite and $0.488 \mathrm{ml}(8.52 \mathrm{mmol})$ of glacial $\mathrm{AcOH}$ were added, and the mixture was refluxed 1 hour. The reaction mixture was shaken with $50 \mathrm{ml}$ of $10 \%$ aqueous $\mathrm{K}_{2} \mathrm{CO}_{3}$. The separated organic phase was then washed with brine, dried $\left(\mathrm{Na}_{2} \mathrm{SO}_{4}\right)$, and concentrated in vacuo to a colorless foam. Formamidetreated silica gel was prepared by mixing well $120 \mathrm{ml}$ of formamide, $600 \mathrm{ml}$ of acetone, and $300 \mathrm{~g}$ silica gel (230 400 mesh), and then removing solvent in vacuo on a rotary evaporator until a freeflowing solid was obtained. The crude product was chromatographed on $300 \mathrm{~g}$ of formamide-impregnated silica gel, eluting with $\mathrm{CHCl}_{3}$ - hexane (98:2). Thus 18 (344 mg, 10\% yield) was isolated as a colorless amorphous solid. Crystallization of $196 \mathrm{mg}$ from acetone $-\mathrm{H}_{2} \mathrm{O}$ yielded $96 \mathrm{mg}$ of colorless crystals.

MP $139 \sim 141{ }^{\circ} \mathrm{C}$; TLC Rf $0.34\left(\mathrm{CH}_{2} \mathrm{Cl}_{2}-\mathrm{MeOH}-\right.$ conc $\left.\mathrm{NH}_{4} \mathrm{OH}, 9: 1: 0.1\right) ;{ }^{13} \mathrm{C}$ NMR Table 1; MS $m / z 774.9\left(\mathrm{M}, \mathrm{C}_{40} \mathrm{H}_{74} \mathrm{O}_{12} \mathrm{~N}_{2}\right), 616.4\left(\mathrm{M}-\mathrm{C}_{8} \mathrm{H}_{16} \mathrm{O}_{2} \mathrm{~N}\right), 458.3142\left(\mathrm{M}-\mathrm{C}_{16} \mathrm{H}_{30} \mathrm{O}_{5} \mathrm{~N}, \mathrm{C}_{24} \mathrm{H}_{44} \mathrm{O}_{7} \mathrm{~N}\right)$, $442.3157\left(\mathrm{M}-\mathrm{C}_{16} \mathrm{H}_{30} \mathrm{O}_{8} \mathrm{~N}, \mathrm{C}_{24} \mathrm{H}_{44} \mathrm{O}_{6} \mathrm{~N}\right), 157.9\left(\mathrm{M}-\mathrm{C}_{32} \mathrm{H}_{88} \mathrm{O}_{10} \mathrm{~N}\right)$.

\section{9-Deoxo-9a-( $\beta$-aminoethyl)-9a-aza-9a-homoerythromycin A (19)}

Sodium borohydride $(1.17 \mathrm{~g}, 31 \mathrm{mmol})$ was added to a mixture of nitrile $3 \mathrm{e}(2.4 \mathrm{~g}, 3.1 \mathrm{mmol})$, $72 \mathrm{ml}$ of $\mathrm{MeOH}$ and anhydrous cobaltous chloride $(0.79 \mathrm{~g}, 6.1 \mathrm{mmol})$ at room temperature. An exothermic reaction occurred, with considerable foaming. The mixture was stirred at room temperature for 2 hours, and then concentrated in vacuo to a black oily residue. The residue was taken up in a $\mathrm{CH}_{2} \mathrm{Cl}_{2}-\mathrm{H}_{2} \mathrm{O}(1: 1)$ mixture $(50 \mathrm{ml})$, and the mixture was stirred for 10 minutes after adjusting the $\mathrm{pH}$ to $2.5(1 \mathrm{~N} \mathrm{HCl})$. The aqueous phase was separated, and then stirred with $25 \mathrm{ml}$ of $\mathrm{CH}_{2} \mathrm{Cl}_{2}$ while the $\mathrm{pH}$ was adjusted to $9.5(1 \mathrm{~N} \mathrm{NaOH})$. The organic phase was then separated, an equal volume of $\mathrm{H}_{2} \mathrm{O}$ added, and the $\mathrm{pH}$ adjusted to $2.0(1 \mathrm{~N} \mathrm{HCl})$. Again, the aqueous phase was separated and then stirred with $25 \mathrm{ml}$ of fresh $\mathrm{CH}_{2} \mathrm{Cl}_{2}$ while the $\mathrm{pH}$ was raised to $9.5(1 \mathrm{~N} \mathrm{NaOH})$. The organic phase was separated, dried (anhydrous $\mathrm{Na}_{2} \mathrm{SO}_{4}$ ), and concentrated in vacuo to a colorless foam (1.15 g). Chromatography of $1.05 \mathrm{~g}$ of the crude product (30 g silica gel, $70 \sim 230 \mathrm{mesh}, \mathrm{CHCl}_{3}-\mathrm{MeOH}-\mathrm{conc}$ $\left.\mathrm{NH}_{4} \mathrm{OH}, 6: 1: 0.1\right)$ yielded $75 \mathrm{mg}(3 \%$ yield) of 19 as a colorless amorphous solid.

${ }^{13} \mathrm{C}$ NMR $\left(100 \mathrm{MHz}, \mathrm{CDCl}_{3}\right) \delta 177.2,102.9,95.2,84.0,78.6,78.0,77.5,77.3,74.3,74.0,73.4$, $72.8,70.9,68.9,68.7,65.5,62.1,53.3,49.4,45.1,41.7,41.6,41.3,40.3(2), 35.0,29.1,28.9,26.7,22.6$, 21.6, 21.3, 21.1, 18.4, 16.2, 15.2, 11.0, 9.7, 7.8; MS m/z 778.6 $\left(\mathrm{M}+1, \mathrm{C}_{99} \mathrm{H}_{78} \mathrm{O}_{12} \mathrm{~N}_{3}\right), 619.4(\mathrm{M}-$ $\left.\mathrm{C}_{8} \mathrm{H}_{10} \mathrm{O}_{2} \mathrm{~N}\right), 158.0\left(\mathrm{M}-\mathrm{C}_{31} \mathrm{H}_{59} \mathrm{O}_{10} \mathrm{~N}_{2}\right)$.

\section{9,11-Deoxo-9a-aza-[11- $\beta, 9 \mathrm{a}$-(epoxyethano)]-9a-homoerythromycin A (20)}

A mixture consisting of amine $19(0.38 \mathrm{~g}, 0.49 \mathrm{mmol})$ in $4 \mathrm{ml}$ of $\mathrm{CHCl}_{3}$, isoamyl nitrite $(0.072 \mathrm{ml}$, $0.54 \mathrm{mmol})$ and glacial $\mathrm{AcOH}(0.056 \mathrm{ml}, 0.98 \mathrm{mmol})$ was refluxed for 1 hour. The addition of isoamyl nitrite and glacial $\mathrm{AcOH}$ (same amount of each just described) was repeated, and the mixture was refluxed for 2 hours. A mixture of $\mathrm{CHCl}_{3}(10 \mathrm{ml})$ and saturated aqueous $\mathrm{NaHCO}_{3}$ solution $(15 \mathrm{ml})$ was added to the reaction, and the $\mathrm{pH}$ of the mixture was adjusted to $9.5(1 \mathrm{~N} \mathrm{NaOH})$. The organic phase was separated, dried (anhydrous $\mathrm{Na}_{2} \mathrm{SO}_{4}$ ), and concentrated in vacuo to afford $0.37 \mathrm{~g}$ of a tan foam. Formamide-treated silica gel was prepared by adding $120 \mathrm{ml}$ of formamide to a well-stirred $300 \mathrm{~g}$ silica gel (230 $240 \mathrm{mesh})-600 \mathrm{ml}$ acetone slurry, and then removing solvent in vacuo on a rotary evaporator until a free-flowing powder was obtained. Chromatography of the crude product on $55 \mathrm{~g}$ of formamide-treated silica gel, and water washing followed by $\mathrm{Na}_{2} \mathrm{SO}_{4}$ drying of productcontaining fractions (to remove formamide) afforded $26.5 \mathrm{mg}$ (about $1 \%$ yield) of $\mathbf{2 0}$ as a white amor- 
phous solid.

${ }^{13} \mathrm{C}$ NMR $\left(250 \mathrm{MHz}, \mathrm{CDCl}_{3}\right) \delta 177.7,103.4,96.0,84.4,79.5,78.1,78.0,74.9,74.3,72.9,71.0(2)$, $68.9,65.8,65.6,65.5,63.1,60.7,50.0,49.4,45.1,41.1,40.6,40.4$ (2), 35.2, 29.7, 29.3, 26.6, 22.6, 21.6, 21.3, 20.9, 18.3, 16.4, 15.5, 11.2, 9.7, 8.5; MS $m / z 602\left(\mathrm{M}-\mathrm{C}_{8} \mathrm{H}_{17} \mathrm{O}_{2} \mathrm{~N}\right), 444.2942\left(\mathrm{M}-\mathrm{C}_{18} \mathrm{H}_{30} \mathrm{O}_{5} \mathrm{~N}\right.$, $\left.\mathrm{C}_{23} \mathrm{H}_{42} \mathrm{O}_{7} \mathrm{~N}\right), 428.3005\left(\mathrm{M}-\mathrm{C}_{18} \mathrm{H}_{30} \mathrm{O}_{6} \mathrm{~N}, \mathrm{C}_{23} \mathrm{H}_{42} \mathrm{O}_{6} \mathrm{~N}\right), 158\left(\mathrm{M}-\mathrm{C}_{31} \mathrm{H}_{58} \mathrm{O}_{10} \mathrm{~N}\right)$.

\section{Acknowledgments}

The authors wish to express their gratitude to Dr. EARL B. WhIpple, Ms. Dianne Rescek, and Mr. Richard S. WARE for providing valuable NMR and mass spectral data.

\section{References}

1) Rigaudy, J. \& S. P. Klesney (Ed.): Section F: General principles for the naming of natural products and related compounds. In Nomenclature of Organic Chemistry. Sections A, B, C, D, E, F and H. pp. $491 \sim 511$, Pergamon Press, New York, 1979

2) Duokic', S.; B. Kamenar, G. Kobrehel, G. Lazarevski, N. Lopotar, A. Nagl, Z. Tamburassev \& I. VICKovic': Erythromycin series. Part II. Ring expansion of erythromycin A oxime by the Beckmann rearrangement. J. Chem. Soc. Perkin Trans. I 1986: 1881 1890, 1986

3) Bright, G. M. (Pfizer): Epimeric azahomoerythromycin A derivative, intermediates and method of use. U.S. 4,526,889, July 2, 1985

4) Barton, D. H. R.; G. Bringmann \& W. B. Motherwell: Radical-induced reductive deamination of amino acid esters. Synthesis: $68 \sim 70,1980$

5) John, D. I.; E. J. Thomas \& N. D. Tyrrell: Reduction of $6 \alpha$-alkyl- $6 \beta$-isocyanopenicillanates by tri- $n$ butyltin hydride. A stereoselective synthesis of $6 \beta$-alkylpenicillanates. J. Chem. Soc. Chem. Commun. 1979: $345 \sim 347,1979$

6) Fieser, L. F. \& M. FIESER (Ed.): Acetic-formic anhydride. In Reagents for Organic Synthesis Vol. 1. p. 4, John Wiley \& Sons, New York, 1967

7) Pfitzner, K. E. \& J. G. Moffatt: Sulfoxide-carbodimide reactions. I. A facile oxidation of alcohols. J. Am. Chem. Soc. 87: $5661 \sim 5670,1965$

8) Sciavolino, F. C. \& M. A. Guadliana (Pfizer): 4"-epi Erythromycin A and derivatives thereof as useful antibacterial agents. U.S. 4,382,085, May 3, 1983

9) Roncari, G. \& W. Keller-Schierlein: Die Konfiguration der arcanose. Helv. Chim. Acta 49: 705 711,1966

10) Howarth, G. B.; W. A. Szarex \& J. K. N. Jones: The synthesis of D-arcanose. Carbohyd. Res. 7: $284 \sim 290,1968$

11) Hauske, J.R. \& A. A. NAGel (Pfizer): 9a-Aza-9a-homoerythromycin compounds, pharmaceutical composition and therapeutic use. U.S. 4,512,982, Apr. 23, 1985

12) SAToh, T.; S. Suzuki, Y. Suzuki, Y. MiYAJI \& Z. IMAI: Reduction of organic compounds with sodium borohydride-transition metal salt systems (1), reduction of organic nitrile, nitro and amide compounds to primary amines. Tetrahedron Lett. 1969: 4555 4558, 1969

13) Girard, A. E.; D. Girard, A. R. English, T. D. Gootz, C. R. Cimochowski, J. A. Faiella, S. L. Haskell \& J.A. Retsema: Pharmacokinetic and in vivo studies with azithromycin (CP-62,993), a new macrolide with an extended half-life and excellent tissue distribution. Antimicrob. Agents Chemother. 31: $1948 \sim 1954,1987$

14) Retsema, J.; A. Girard, W. Schelkly, M. Manousos, M. Anderson, G. Bright, R. Borovoy, L. BRENNAN \& R. MASON: Spectrum and mode of action of azithromycin (CP-62,993), a new 15-memberedring macrolide with improved potency against Gram-negative organisms. Antimicrob. Agents Chemother. 31: $1939 \sim 1947,1987$

15) Ericsson, H. M. \& J. C. Sherris: Antibiotic sensitivity testing-report of an international collaborative study. Acta Pathol. Microbiol. Scand. Suppl. 217B: 64 68, 1971

16) Steers, E.; E. L. Foltz \& B. S. Graves: An inocula replicating apparatus for routine testing of bacterial susceptibility to antibiotics. Antibiot. Chemother. 9: 307 311, 1959

17) English, A. R.; J. A. Retsema, A. E. Girard, J. E. LynCH \& W. E. BARth: CP-45,899, a beta-lactamase inhibitor that extends the antibacterial spectrum of beta-lactams: Initial bacteriological characterization. Antimicrob. Agents Chemother. 14: 414 419, 1978 
18) Retsema, J. A.; A. R. English, A. Girard, J. E. Lynch, M. Anderson, L. Brennan, C. Cimochowski, J. Faiella, M. Norcia \& P. SAwYer: Sulbactam/ampicillin: In vitro spectrum, potency, and activity in models of acute infection. Rev. Infec. Dis. 6 (Suppl. 5): S528 S534, 1986

19) Batson, H. E. (Ed.): An Introduction to Statistics in the Medical Sciences. pp. 64 67, Burgess Publishing Co., Minneapolis, 1957 